San Jose State University

SJSU ScholarWorks

Master's Theses

Master's Theses and Graduate Research

1996

\title{
The synthesis and reactivity of an anionic zirconium complex as a methylation reagnet : $\mathrm{K}\left[(\mathrm{Ot}-\mathrm{Bu})_{3} \mathrm{Zr}\left(\mathrm{CH}_{3}\right)_{2}\right]$
}

Seon-Joong Kim

San Jose State University

Follow this and additional works at: https://scholarworks.sjsu.edu/etd_theses

\section{Recommended Citation}

Kim, Seon-Joong, "The synthesis and reactivity of an anionic zirconium complex as a methylation reagnet : K[(Ot-Bu $\left.)_{3} \mathrm{Zr}\left(\mathrm{CH}_{3}\right)_{2}\right] "$ (1996). Master's Theses. 1314.

DOI: https://doi.org/10.31979/etd.cuht-p6f6

https://scholarworks.sjsu.edu/etd_theses/1314

This Thesis is brought to you for free and open access by the Master's Theses and Graduate Research at SJSU ScholarWorks. It has been accepted for inclusion in Master's Theses by an authorized administrator of SJSU ScholarWorks. For more information, please contact scholarworks@sjsu.edu. 


\section{INFORMATION TO USERS}

This manuscript has been reproduced from the microfilm master. UMI films the text directly from the original or copy submitted. Thus, some thesis and dissertation copies are in typewriter face, while others may be from any type of computer printer.

The quality of this reproduction is dependent upon the quality of the copy submitted. Broken or indistinct print, colored or poor quality illustrations and photographs, print bleedthrough, substandard margins, and improper alignment can adversely affect reproduction.

In the unlikely event that the author did not send UMI a complete manuscript and there are missing pages, these will be noted. Also, if unauthorized copyright material had to be removed, a note will indicate the deletion.

Oversize materials (e.g., maps, drawings, charts) are reproduced by sectioning the original, beginning at the upper left-hand corner and continuing from left to right in equal sections with small overlaps. Each original is also photographed in one exposure and is included in reduced form at the back of the book.

Photographs included in the original manuscript have been reproduced xerographically in this copy. Higher quality 6" 19 " black and white photographic prints are available for any photographs or illustrations appearing in this copy for an additional charge. Contact UMI directly to order.

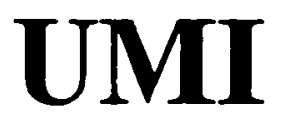

A Bell \& Howell Information Company 300 North Zeeb Road, Ann Arbor MI 48106-1346 USA 



\title{
THE SYNTHESIS AND REACTIVITY OF AN ANIONIC ZIRCONIUM COMPLEX AS A METHYLATION REAGNET: \\ $\mathrm{K}\left[(\mathrm{O} t-\mathrm{Bu})_{3} \mathrm{Zr}\left(\mathrm{CH}_{3}\right)_{2}\right]$
}

\author{
A Thesis \\ Presented to \\ The Faculty of the Department of Chemistry \\ San Jose State University
}

\author{
In Partial Fulfillment \\ of the Requirements for the Degree \\ Master of Science
}

By

Seon-Joong Kim

August, 1996 
UMI Number: 1381425

\section{Copyright 1996 by \\ Rim, Seon-Joong}

All rights reserved.

UMI Microform 1381425

Copyright 1996, by UMI Company. All rights reserved.

This microform edition is protected against unauthorized copying under Title 17, United States Code.

\section{UMI \\ 300 North Zeeb Road \\ Ann Arbor, MI 48103}


01996

Seon-Joong Kim

ALL RIGHTS RESERVED 
APPROVED FOR THE DEPARTMENT OF CHEMISTRY
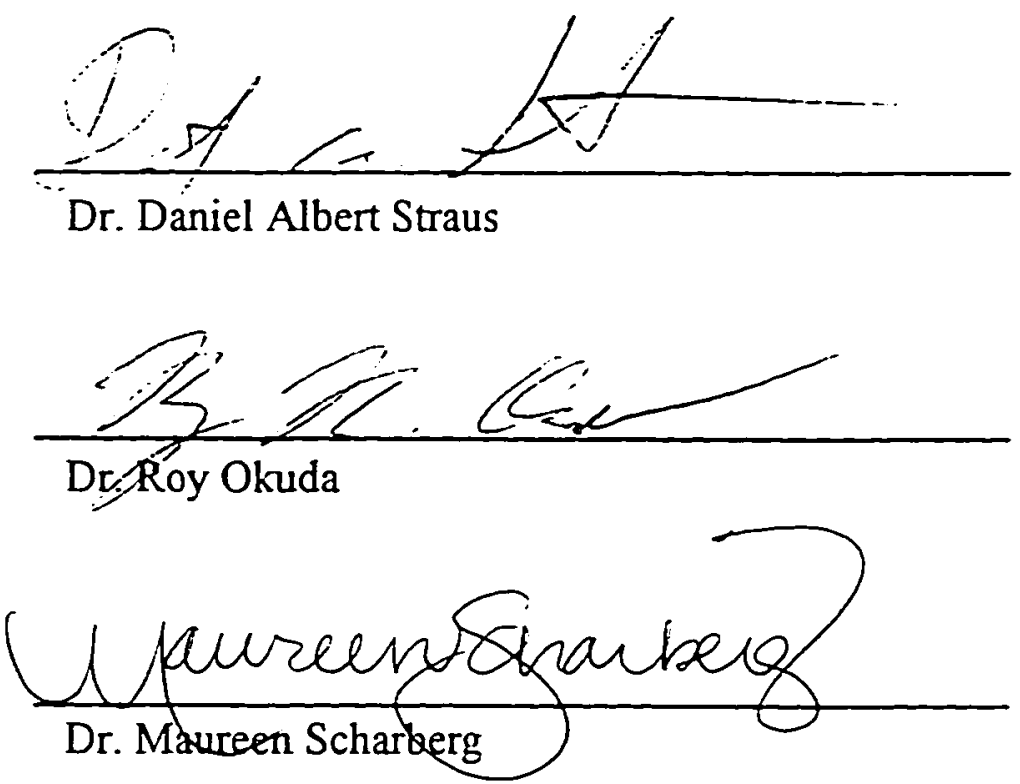

APPROVED FOR THE UNIVERSITY

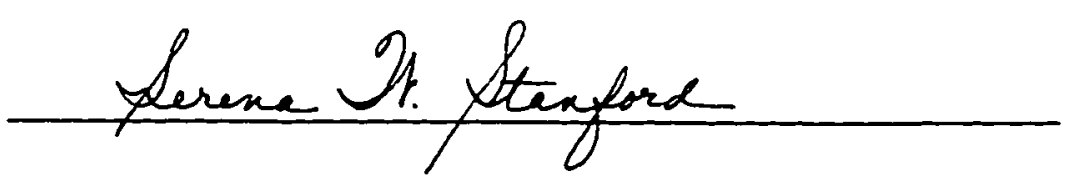




\section{ABSTRACT \\ THE SYNTHESIS AND REACTIVITY OF AN ANIONIC ZIRCONIUM COMPLEX AS A METHYLATION REAGENT: $\mathrm{K}\left[(\mathrm{O} t-\mathrm{Bu})_{3} \mathrm{Zr}\left(\mathrm{CH}_{3}\right)_{2}\right]$}

\section{by Seon-Joong Kim}

Previously in our laboratory, we discovered the methylation of carbonyl compounds by $\mathrm{Cp}_{2} \mathrm{Zr}\left(\mathrm{CH}_{3}\right)_{2}\left(\mathrm{Cp}=\eta^{5}-\mathrm{C}_{5} \mathrm{H}_{5}\right)$ in the presence of excess $\mathrm{KO} t-\mathrm{Bu}$ and proposed a zirconium "ate" complex, $\mathrm{K}\left[(\mathrm{O} t-\mathrm{Bu})_{3} \mathrm{Zr}\left(\mathrm{CH}_{3}\right)_{2}\right](1)$, as an active intermediate. Although our postulated in situ generated "ate" intermediate will methylate non-enolizable aldehydes and ketones, there was no methylation observed for enolizable ketones.

Herein we report the isolation of complex 1 as a white powder. From the spectral data $\left({ }^{1} \mathrm{H}\right.$ and ${ }^{13} \mathrm{C}$ NMR) and elemental analysis, complex 1 contains $<1 \%$ of $\mathrm{KCp}$ and unknown impurities. Concerning the use of this methylation reagent in organic synthesis, we have found that it (i) reacts smoothly with aldehydes and even with enolizable ketones, (ii) shows high aldehyde-selectivity ( $>99 \%$ ) with equimolar mixtures of aldehyde and ketone, and (iii) gives modest diastereoselectivity (85\%) in the methylation of 4-tert-butylcyclohexanone. The isolated complex 1 is compared with the in situ system. 
To my wife, Chun Hee, and my son, Sun Whee 


\section{ACKNOWLEDGMENTS}

Many people must be thanked for their assistance, help and encouragement in making this thesis possible. Dr. Dan Straus was always there to support me through the research, paperwork, presentations and deadlines; to my committee members Drs. Maureen Scharberg and Roy Okuda, gave their careful comments and suggestions throughout the entire process; Dr. Dick Gaver first inspired me to study at San Jose State University; Rachel O'Ryan taught me English during my research: To each of these people, and to so many more, goes my gratitude for the time and effort extended on my behalf. The most special thanks and gratitude go to my family, especially my parents without whose support I would not have been able to complete my studies. 


\section{TABLE OF CONTENTS}

Page

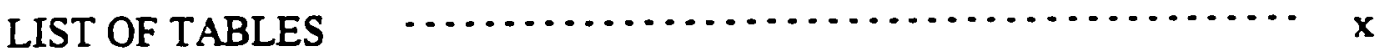

LIST OF FIGURES AND SCHEMES $\quad \cdots \ldots \ldots \ldots \ldots \ldots \ldots \ldots \ldots \ldots \ldots \ldots$

Chapter I. Organozirconium Complexes in Organic Synthesis $\cdots \cdots \cdots \cdots \cdots$

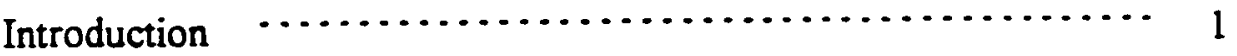

Discussion of Previous Work $\ldots \ldots \ldots \ldots \ldots \ldots \ldots \ldots \ldots \ldots \ldots$

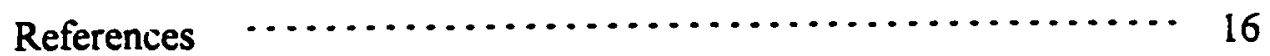

Chapter II. Preparation of Anionic Alkoxyalkylzirconium Complexes …… 18

Introduction $\cdots \ldots \ldots \ldots \ldots \ldots \ldots \ldots \ldots \ldots \ldots \ldots \ldots \ldots \ldots \ldots \ldots \ldots \ldots, 18$

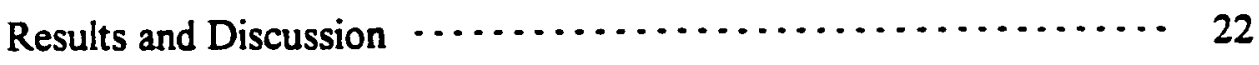

A. Synthesis and Spectroscopic Properties of $\mathrm{K}\left[(\mathrm{t}-\mathrm{BuO})_{3} \mathrm{Zr}\left(\mathrm{CH}_{3}\right)_{2}\right](1) \quad \ldots \ldots \ldots \ldots \ldots \ldots \ldots \ldots \ldots \ldots \ldots \ldots \ldots \ldots \ldots \ldots$

B. Other Attempted Reactions $\ldots \ldots \ldots \ldots \ldots \ldots \ldots \ldots \ldots \ldots \ldots$

1. Reaction of $\mathrm{Cp}_{2} \mathrm{ZrPh}_{2}$ with $4 \mathrm{KO} t-\mathrm{Bu} \quad \ldots \ldots \ldots \ldots 27$

2. Reaction of $\mathrm{Cp}_{2} \mathrm{Zr}\left(\mathrm{CH}_{2} \mathrm{Ph}\right)_{2}$ with $4 \mathrm{KO}$ - $-\mathrm{Bu} \quad \ldots \ldots .27$

3. Reaction of $\mathrm{Zr}\left(\mathrm{CH}_{2} \mathrm{Ph}\right)_{4}$ with $\mathrm{KO} t-\mathrm{Bu} \quad \ldots \ldots \ldots .29$

Experimental $\ldots \ldots \ldots \ldots \ldots \ldots \ldots \ldots \ldots \ldots \ldots \ldots \ldots \ldots, 31$

A. General Procedure $\ldots . \ldots \ldots \ldots \ldots \ldots \ldots \ldots \ldots \ldots . . \ldots 1$

B. Materials $\ldots \ldots \ldots \ldots \ldots \ldots \ldots \ldots \ldots \ldots \ldots \ldots . \ldots . \ldots . \ldots$

C. NMR tube reactions in THF- $d_{8} \quad \ldots \ldots \ldots \ldots \ldots \ldots \ldots \ldots, 32$

1. $\mathrm{Cp}_{2} \mathrm{ZrPh}_{2}$ with $4 \mathrm{KO}$-Bu $\quad \ldots \ldots \ldots \ldots \ldots \ldots \ldots . \ldots . .32$ 
2. $\mathrm{Cp}_{2} \mathrm{Zr}\left(\mathrm{CH}_{2} \mathrm{Ph}\right)_{2}$ with $4 \mathrm{KOt}-\mathrm{Bu} \quad \cdots \cdots \cdots \cdots \cdots \cdots \cdots \cdots \cdots$

3. $\mathrm{Zr}\left(\mathrm{CH}_{2} \mathrm{Ph}\right)_{4}$ with $\mathrm{KO} t-\mathrm{Bu} \quad \cdots \ldots \ldots \ldots \ldots \ldots, 32$

D. Reactions of $\mathrm{Zr}\left(\mathrm{CH}_{2} \mathrm{Ph}\right)_{4}$ with $\mathrm{KO}$ t-Bu $\quad \cdots \ldots \ldots \ldots \ldots, \quad 32$

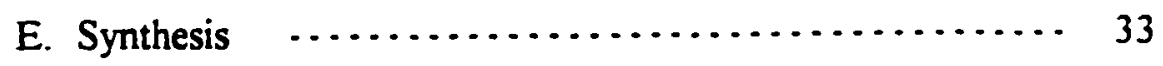

1. $\mathrm{K}\left[(t-\mathrm{BuO})_{3} \mathrm{Zr}\left(\mathrm{CH}_{3}\right)_{2}\right] \quad \cdots \ldots \ldots \ldots \ldots \ldots \ldots, 33$

2. $\mathrm{Cp}_{2} \mathrm{ZrPh}_{2} \quad \ldots \ldots \ldots \ldots \ldots \ldots \ldots \ldots \ldots \ldots \ldots \ldots \ldots \ldots, 34$

3. $\mathrm{Cp}_{2} \mathrm{Zr}\left(\mathrm{CH}_{3}\right)_{2} \ldots \ldots \ldots \ldots \ldots \ldots \ldots \ldots \ldots \ldots \ldots \ldots \ldots \ldots$

References $\quad \ldots \ldots \ldots \ldots \ldots \ldots \ldots \ldots \ldots \ldots \ldots \ldots \ldots \ldots \ldots \ldots \ldots, \quad 38$

Chapter III. Reactivity of $\mathrm{K}\left[(\mathrm{t}-\mathrm{BuO})_{3} \mathrm{Zr}\left(\mathrm{CH}_{3}\right)_{2}\right]$ (1) with Carbonyl

Substrates $\ldots \ldots \ldots \ldots \ldots \ldots \ldots \ldots \ldots \ldots \ldots \ldots \ldots \ldots \ldots, 40$

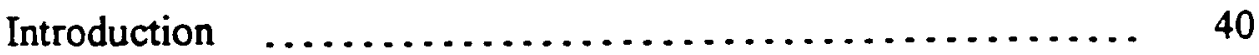

Results and Discussion $\quad \ldots \ldots \ldots \ldots \ldots \ldots \ldots \ldots \ldots \ldots . . . \ldots \ldots \ldots$

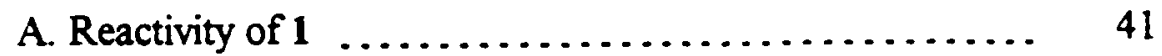

1. Yields $\ldots \ldots \ldots \ldots \ldots \ldots \ldots \ldots \ldots \ldots \ldots \ldots, 41$

2. Reaction products from benzaldehyde $\ldots \ldots \ldots .43$

3. Reaction with acetophenone and cyclohexanone ${ }^{-\cdot} 44$

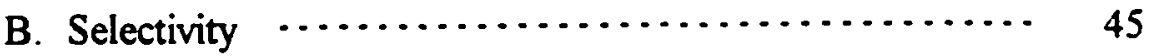

1. Benzaldehyde vs. other aldehydes $\cdots \ldots \ldots \ldots . .45$

2. Benzaldehyde vs. ketones $\cdots \ldots \ldots \ldots \ldots \ldots, 47$

C. Diastereoselectivity $\quad \cdots \ldots \ldots \ldots \ldots \ldots \ldots \ldots \ldots \ldots, \quad 50$

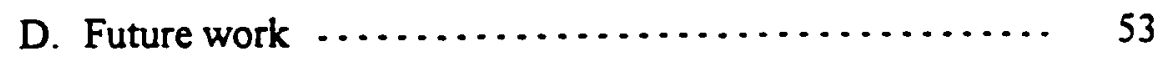

Experimental $\ldots \ldots \ldots \ldots \ldots \ldots \ldots \ldots \ldots \ldots \ldots \ldots \ldots \ldots \ldots \ldots \ldots, 53$

viii 
A. General Procedures and Materials $\ldots \ldots \ldots \ldots \ldots \ldots \ldots . . .63$

B. Specific Procedure $\ldots \ldots \ldots \ldots \ldots \ldots \ldots \ldots \ldots \ldots \ldots \ldots \ldots$

1. Preparation of a standard solution for gas chromatography $\quad \ldots \ldots \ldots \ldots \ldots \ldots \ldots \ldots . . \ldots . \ldots$

2. Example of a competition reaction $\ldots \ldots \ldots \ldots \ldots 55$

References $\ldots \ldots \ldots \ldots \ldots \ldots \ldots \ldots \ldots \ldots \ldots \ldots \ldots \ldots \ldots \ldots, 56$ 


\section{LIST OF TABLES}

Page

Chapter I.

Table 1. The general properties of selected zirconium alkoxides $\cdots \cdots$

Table 2. Comparison of the selectivity in the competition reactions with equimolar mixtures of benzaldehyde and

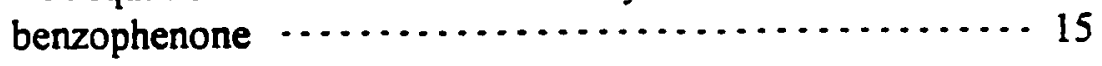

Table 3. Comparison of the ${ }^{1} \mathrm{H}$ and ${ }^{13} \mathrm{C}$ NMR methyl peaks in methyl zirconium complexes

Chapter II.

Table $1 .{ }^{1} \mathrm{H}$ and ${ }^{13} \mathrm{C}$ NMR chemical shift data for various $\mathrm{O}-\mathrm{C}^{1}\left(\mathrm{C}^{2} \mathrm{H}_{3}\right)_{3}$ and $\mathrm{Zr}-\mathrm{CH}_{3}$ complexes in THF- $d_{8} \quad \ldots \ldots \ldots \ldots \ldots \ldots, 26$

Table 2. ${ }^{1} \mathrm{H}$ NMR data for $\mathrm{O}-\mathrm{C}\left(\mathrm{CH}_{3}\right)_{3}$ and $\mathrm{Zr}-\mathrm{CH}_{3} \mathrm{C}_{6} \mathrm{H}_{5}$ comple in $\mathrm{THF}-d_{8} \ldots \ldots \ldots \ldots \ldots \ldots \ldots \ldots \ldots \ldots \ldots, 30$

Chapter III.

Table 1. Methylation with 1 in $\mathrm{THF}$ at $0^{\circ} \mathrm{C}$ for $30 \mathrm{~min}$.

Table 2. Methylation of acetophenone in THF at $0{ }^{\circ} \mathrm{C}$ for $30 \mathrm{~min}$. $\cdots 44$

Table 3. Competition reactions of 1 with benzaldehyde and various ketones in THF at $0^{\circ} \mathrm{C}$ for $30 \mathrm{~min}$. $\cdots \cdots \cdots \cdots \cdots \cdots$

Table 4. Comparison of the selectivity in the reaction of various methylation reagents with equimolar mixtures of benzaldehyde and acetophenone

Table 5. Comparison of the selectivity in the reaction of various methylation reagents with equimolar mixtures of benzaldehyde and benzophenone

Table 6. Diastereoselective addition to 4-tert-butylcyclohexanone $\cdots 51$ 


\section{LIST OF FIGURES AND SCHEMES}

Page

Chapter I.

Figure 1. Oxophilic or fluorophilic effects $\cdots \ldots \ldots \ldots \ldots \ldots \ldots \ldots$

Scheme 1. $\mathrm{Cp}_{2} \mathrm{Zr}(\mathrm{H}) \mathrm{Cl}$ reaction with alkenes and alkynes $\quad \cdots \cdots \cdot \cdot 3$

Figure 2. Cleavage of the $\mathrm{Zr}-\mathrm{C}$ bond by bromine $\cdots \cdots \cdots \cdots \cdots$

Scheme 2. Alkylation of aldehydes by alkyizirconocene chloride with $\mathrm{Ag}(\mathrm{I})$ catalyst $\quad \ldots \ldots \ldots \ldots \ldots \ldots \ldots \ldots \ldots \ldots \ldots \ldots \ldots \ldots \ldots$

Figure 3. Cationic zirconocene species $\ldots \ldots \ldots \ldots \ldots \ldots \ldots \ldots \ldots$

Scheme 3. Two resonance structures of " $\mathrm{C}_{2} \mathrm{Zr}$ " - olefin complexes $\ldots 7$

Scheme 4. Isolated zirconocene-benzyne and zirconocene-cyclohexyne complexes $\ldots \ldots \ldots \ldots . . .99$

Scheme 5. Aryloxy(2,6-di-tert-butylphenoxide) zircononium complex $\ldots \ldots \ldots \ldots \ldots \ldots \ldots \ldots \ldots \ldots, 11$

Scheme 6. Alkyltitanium reagents $\ldots \ldots \ldots \ldots \ldots \ldots \ldots \ldots, 12$

Scheme 7. Reaction with $\alpha$-tetralone $\ldots \ldots \ldots \ldots \ldots \ldots \ldots \ldots, 13$

Scheme 8. Possible intermediates in the alkylation with zirconocene alkyls $\ldots \ldots \ldots \ldots \ldots \ldots \ldots \ldots \ldots, 14$

Chapter II.

Scheme 1. Anionic zirconocene ketene complexes $\ldots \ldots \ldots \ldots . .18$

Scheme 2. Anionic alkynylzirconocene $\ldots \ldots \ldots \ldots \ldots \ldots \ldots \ldots . .20$

Scheme 3. Anionic titanium alkoxides $\ldots \ldots \ldots \ldots \ldots \ldots \ldots . . \ldots 21$

Scheme 4. Properties of complex $1 \quad \ldots \ldots \ldots \ldots \ldots \ldots \ldots \ldots . \ldots . \ldots . \ldots . \ldots$ 
Figure 1. ${ }^{1} \mathrm{H}$ NMR spectrum of $\mathrm{K}\left[(t-\mathrm{BuO})_{3} \mathrm{Zr}\left(\mathrm{CH}_{3}\right)_{2}\right]$ in THF- $d_{8}$ solution $\ldots \ldots \ldots \ldots \ldots \ldots \ldots \ldots \ldots \ldots, 24$

Figure 2. ${ }^{i 3} \mathrm{C}$ NMR spectrum (with APT) of $\mathrm{K}\left[(\boldsymbol{t}-\mathrm{BuO})_{3} \mathrm{Zr}\left(\mathrm{CH}_{3}\right)_{2}\right]$ in $\mathrm{THF}-d_{8}$ solution $\cdots \ldots \ldots \ldots \ldots \ldots \ldots, 25$

Scheme 5. Reaction of $\mathrm{Cp}_{2} \mathrm{ZrPh}_{2}$ with $3 \mathrm{KO} t-\mathrm{Bu} \ldots \ldots \ldots \ldots \ldots \ldots, 28$

Figure 3. ${ }^{1} \mathrm{H}$ NMR spectrum of product from KOt-Bu $+\mathrm{Zr}\left(\mathrm{C}_{6} \mathrm{H}_{6} \mathrm{CH}_{2}\right)_{4}$ in THF $-d_{8}$ solution $\quad \cdots \ldots \ldots \ldots \ldots \ldots \ldots \ldots, 30$

Figure 4. ${ }^{13} \mathrm{C} N M R$ spectrum of $\mathrm{Cp}_{2} \mathrm{ZrPh}_{2}$ in $\mathrm{C}_{6} \mathrm{D}_{6} \ldots \ldots \ldots \ldots \ldots, 36$

Figure 5. ${ }^{13} \mathrm{C}$ NMR spectrum of the mixture of $\mathrm{Cp}_{2} \mathrm{ZrPh}_{2}$ and

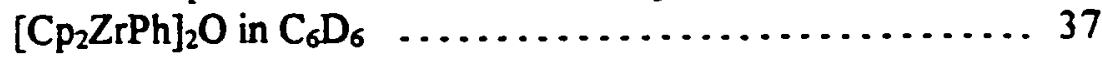

Figure 6. ${ }^{13} \mathrm{C}$ NMR spectrum of $\left[\mathrm{Cp}_{2} \mathrm{ZrPh}\right]_{2} \mathrm{O}$ in $\mathrm{C}_{6} \mathrm{D}_{6} \quad \ldots \ldots \ldots \ldots . .37$

Chapter III.

Figure 1. Methylation of benzaldehyde with complex 1 in THF for $30 \mathrm{~min}$. Figures in brackets represent $\mathrm{GC}$ retention time (min.) 43

Scheme 1. Meerwein-Ponndorf-Verley reduction 44

Scheme 2. Mechanism of the recovery of acetophenone 45

Scheme 3. Competition reactions of 1 with benzaldehyde and various aldehydes 46

Scheme 4. Methylation of 4-tert-butylcyclohexanone 50 


\section{Chapter I.}

\section{Organozirconium Complexes in Organic Synthesis}

\section{Introduction}

Selective formation carbon-carbon $\sigma$-bonds using organozirconium reagents has increased over the last fifteen years due to the development of organozirconium reactions such as hydrozirconation ${ }^{1}$ and cross-coupling reactions ${ }^{2}$. Organozirconium reagents have become popular among organic chemists for use in synthesis because of their high stereo-, regio-, and chemo-selectivities. Some of the chemistry of these complexes most relevant to our work is presented below.

\section{Discussion of Previous Work}

In general, $\operatorname{Zr}\left(4 s^{2} 5 s^{2}\right)$ prefers the +4 oxidation state $\left(d^{0}\right)$ and 16-electron complexes, which means that the empty $d$-orbital can accept electron density from the lone pairs of oxygen or halide ligands. These strong oxygen or halide bonds with early transition metals are called oxophilic or fluorophilic effects (see Figure 1). ${ }^{3}$

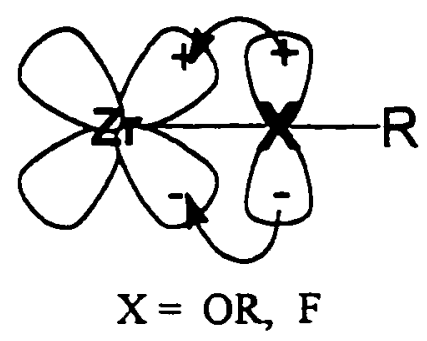

Fig. 1. 
The zirconocenes, having the moiety $\mathrm{Cp}_{2} \mathrm{Zr}\left(\mathrm{Cp}=\eta^{5}-\mathrm{C}_{5} \mathrm{H}_{5}\right)$, are the best studied complexes of organozirconium compounds. The common neutral metallocene complexes are exemplified by $\mathrm{Cp}_{2} \mathrm{ZrXY}(\mathrm{X}, \mathrm{Y}=\mathrm{H}, \mathrm{R}$, or halide). The simplest synthetic approach to organozirconocene reagents is transmetallation, the transfer of an organic group from one metal to a different metal. For example, the complex $\mathrm{Cp}_{2} \mathrm{Zr}\left(\mathrm{CH}_{3}\right)_{2}$ is conveniently obtained from the appropriate dichloride $\left(\mathrm{C}_{2} \mathrm{ZrCl}_{2}\right)$ and methyllithium ${ }^{4}$ as a white crystalline solid which is sublimed readily in vacuo (Eq.1).

$$
\mathrm{Cp}_{2} \mathrm{ZrCl}_{2}+2 \mathrm{CH}_{3} \mathrm{Li} \longrightarrow \mathrm{Cp}_{2} \mathrm{Zr}\left(\mathrm{CH}_{3}\right)_{2}+2 \mathrm{LiCl}
$$

Although the reactivity of dimethylzirconocene, $\mathrm{Cp}_{2} \mathrm{Zr}\left(\mathrm{CH}_{3}\right)_{2}$, with diphenylketene or phenylisocyanate ${ }^{5}$ was reported in 1985 (Eq. 2), these insertion reactions have not yet been developed for synthetic use.

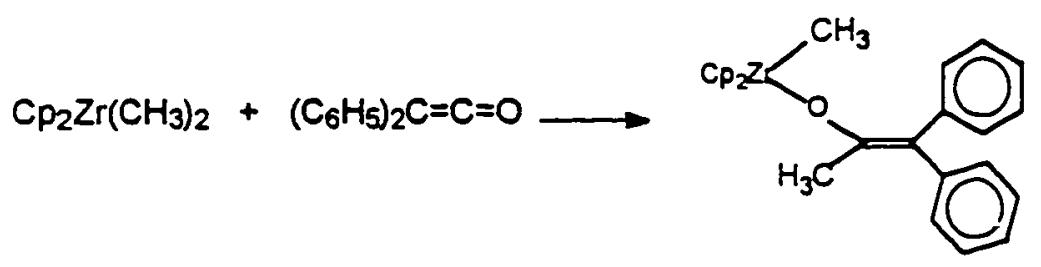

The first widely used organozirconium reagent in organic synthesis is $\mathrm{Cp}_{2} \mathrm{Zr}(\mathrm{H}) \mathrm{Cl}$. This hydride was first prepared in 1969 by Wailes ${ }^{6}$ from $\mathrm{Cp}_{2} \mathrm{ZrCl}_{2}$ and $\mathrm{LiAlH}_{4}$. In the mid- 
1970s, Schwartz $z^{1,7}$ developed "hydrozirconation" reactions: the $\mathrm{d}^{0} \mathrm{Zr}(\mathrm{IV})$ complex $\mathrm{Cp}_{2} \mathrm{Zr}(\mathrm{H}) \mathrm{Cl}$ reacts with a number of alkenes and alkynes to give stable, isolable alkyl and alkenyl complexes of the type $\mathrm{C}_{2} \mathrm{Zr}(\mathrm{R}) \mathrm{Cl}$ as shown in Scheme 1. This zirconium-carbon bond is formed regiospecifically because of the steric bulk of the zirconocene moiety, such that the $\mathrm{Zr}$ adds at the sterically least-hindered carbon atom of the alkene. For example, when 4-octene reacts with $\mathrm{Cp}_{2} \mathrm{Zr}(\mathrm{H}) \mathrm{Cl}$, a sequence of $\beta-\mathrm{H}$ elimination and re-addition will occur until the least hindered (most stable) final product is formed (Scheme 1). Schwartz developed useful transformations of these alkyl complexes by reaction with various electrophiles. For example, protonation produces the hydrocarbon and bromination with

Scheme 1.
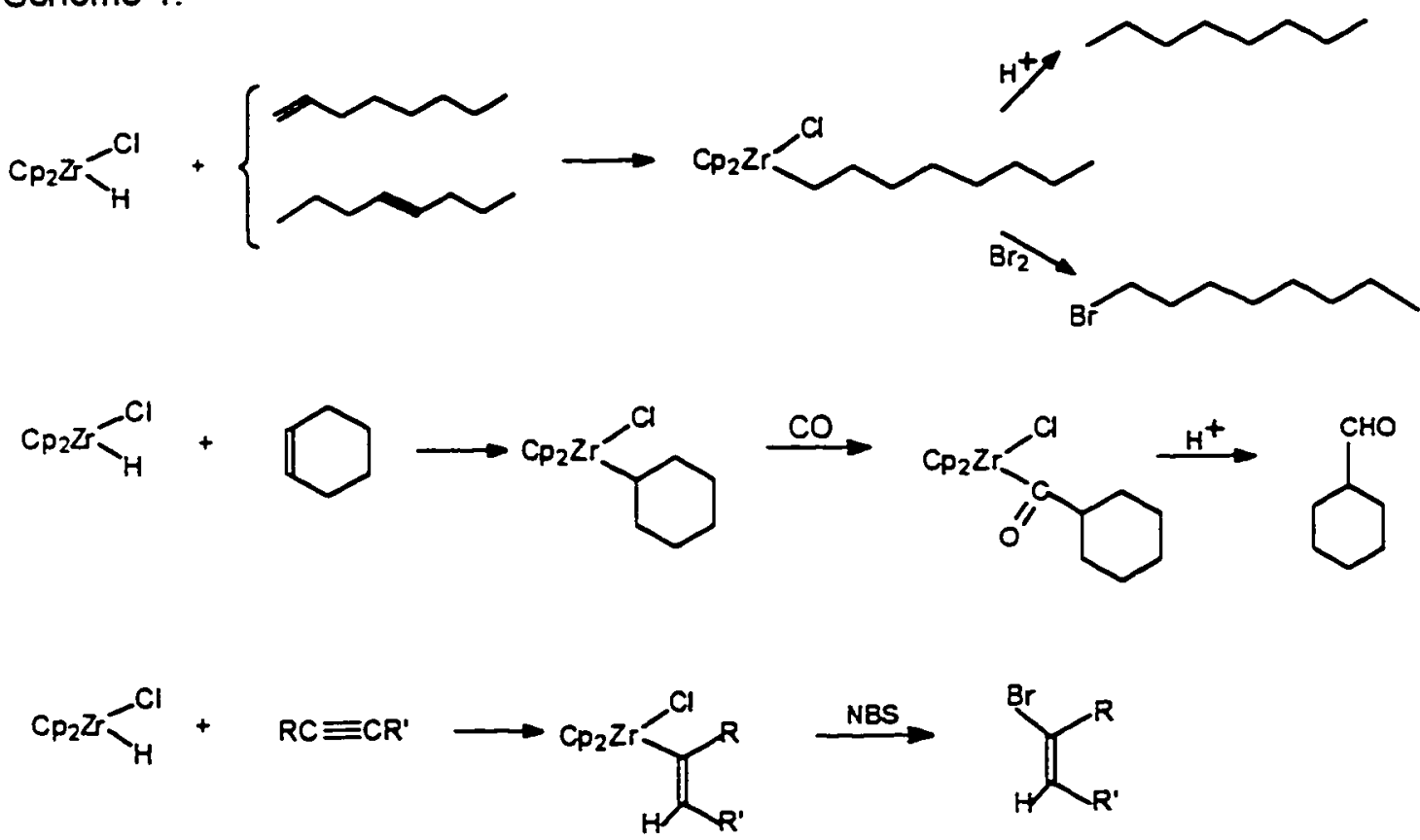
$\mathrm{Br}_{2}$ (or $\mathrm{N}$-bromosuccinimide, NBS) gives the alkyl bromide. The acyl zirconium complex, resulting from facile $\mathrm{CO}$ insertion under mild conditions $\left(25^{\circ} \mathrm{C}, 20 \mathrm{psi}\right)$, reacts with dilute $\mathrm{HCl}$ to produce the aldehyde (Scheme $\mathrm{l}$ ). Cleavage of the $\mathrm{Zr}-\mathrm{C}$ bond by bromine proceeds with retention of configuration at carbon (Figure 2).

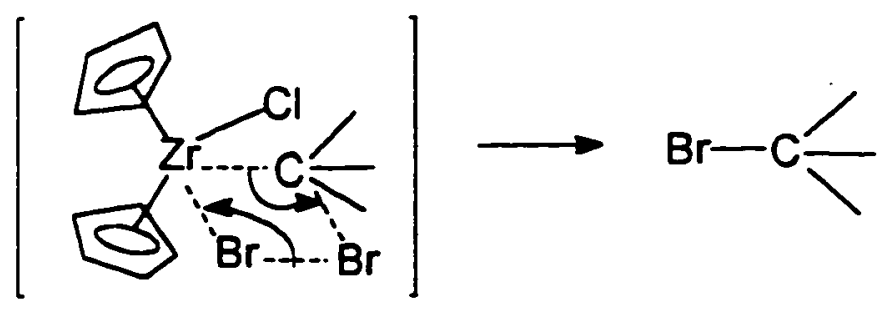

Fig. 2.

However, these zirconocene alkyl (or alkenyl) chlorides, $\mathrm{Cp}_{2} \mathrm{Zr}(\mathrm{R}) \mathrm{Cl}$, have poor reactivity toward carbon electrophiles such as alkyl halides, aldehydes, ketones and $\alpha, \beta$-unsaturated carbonyl derivatives. This observation led to the development of transmetallation from zirconium to another metal which has better carbon-carbon bond forming ability. In 1994, the Wipf group ${ }^{8}$ reported the copper-catalyzed conjugate addition of an alkylzirconocene to an enone (Eq. 3); reaction of hexylzirconocene with 2-cyclohexenone in the presence of $\mathrm{Cu}(\mathrm{I})$ leads to the 1,4-addition ketone product. 


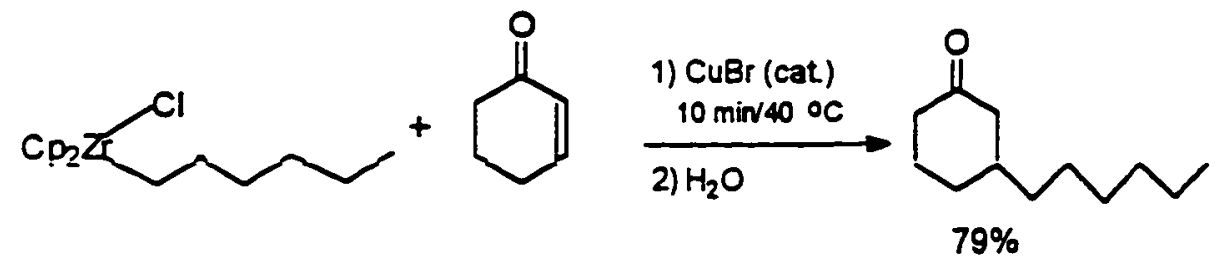

In 1995, the Suzuki group ${ }^{9}$ found that $\mathrm{AgAsF}_{6}$ is an effective catalyst for alkylation of aldehydes by alkylzirconocene chloride (Scheme 2). There is no reactivity with aldehydes in the absence of catalyst. In their previous reports, ${ }^{96, c}$ cationic zirconocene species are proposed as key intermediates to activate carbonyl groups

Scheme 2.

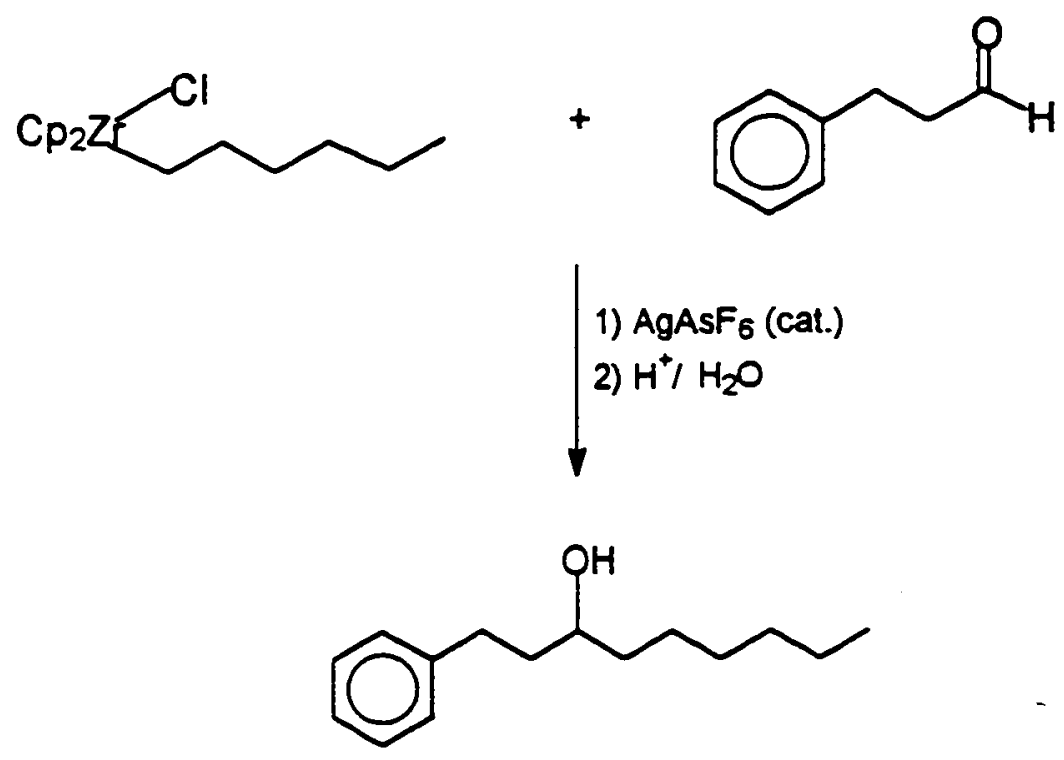

$95 \%$ 
(Figure 3). Although the $\mathrm{Ag}(\mathrm{I})$-catalyzed activation of alkyl (or alkenyl) zirconocene works well for aldehydes, it does not occur with ketones, for either alkyl or alkenyl transfer.

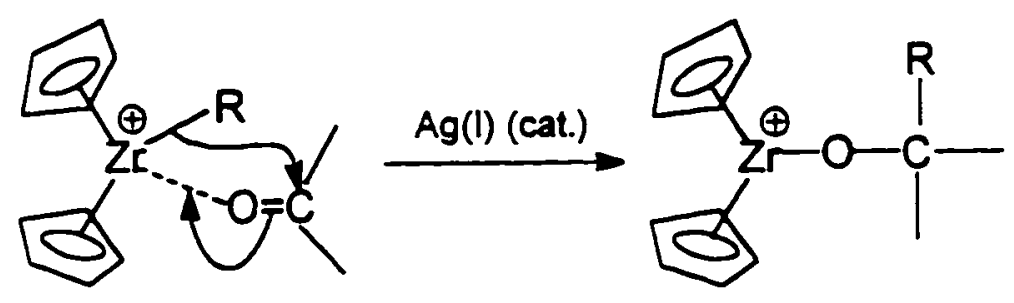

Fig. 3

Recently, the in situ generated $\mathrm{Zr}$ (II) complex, " $\mathrm{C} \mathrm{p}_{2} \mathrm{Zr}$ ", (a hypothetical $\mathrm{d}^{2}$, 14-electron species referred to as the Negishi reagent) ${ }^{2},{ }^{10}$ has been extensively developed for organic synthesis because of its wide applicability and effectiveness for ring construction. As can be seen Scheme 3, this reagent is prepared in situ from zirconocene dichloride, $\mathrm{Cp}_{2} \mathrm{ZrCl}_{2}$, and two equivalents of $n$-butyllithium $\left(-78{ }^{\circ} \mathrm{C}-0{ }^{\circ} \mathrm{C}\right)$. Two resonance structures (A and $\mathbf{B}$ in Scheme 3) describe the intermediate. The formal oxidation state of $\mathrm{Zr}$ in resonance structure $\mathrm{A}$ is +2 because the $\pi$-bond of butene acts as a two-electron $\sigma$-donor ligand. 


\section{Scheme 3.}
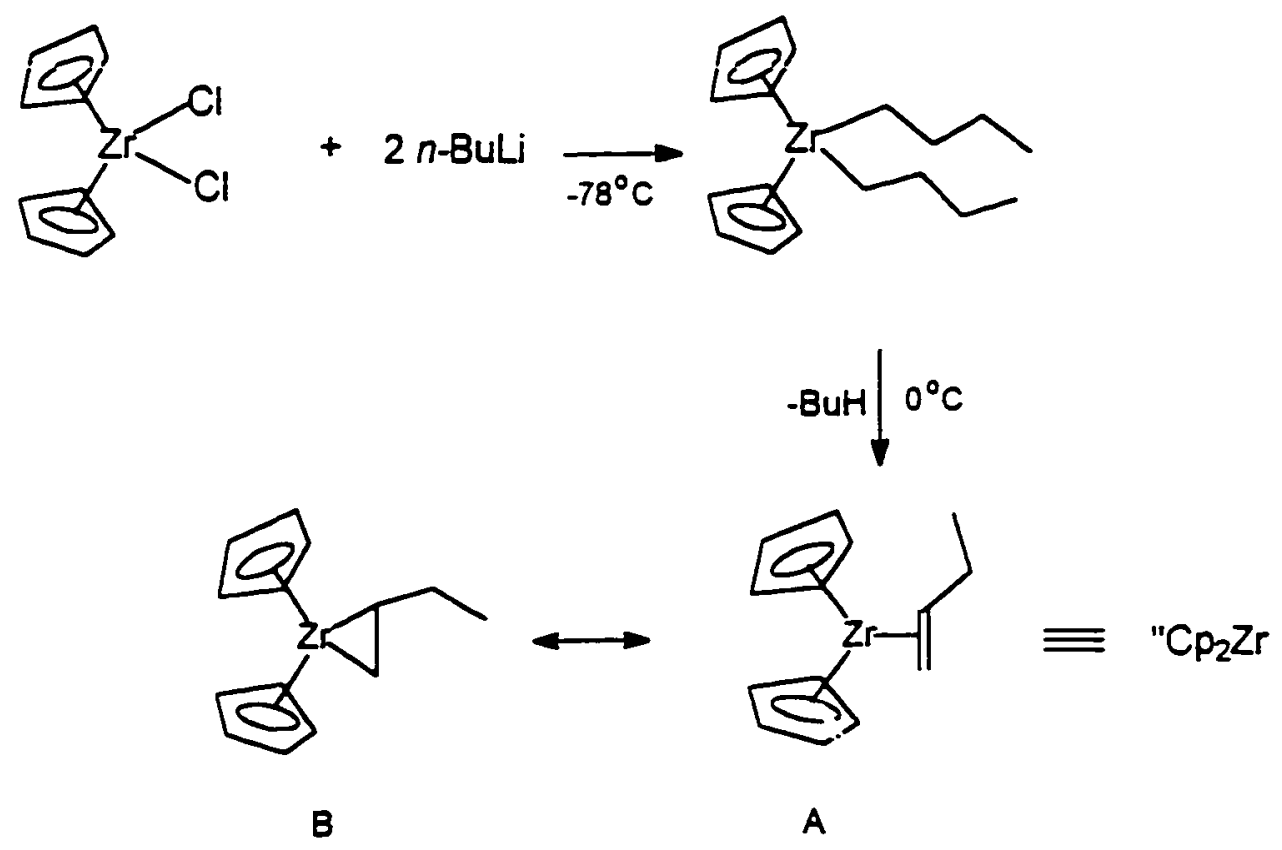

One important reaction of " $\mathrm{Cp}_{2} \mathrm{Zr}$ " is the intramolecular insertion of dienes or eneynes. For example, 7-(trimethylsilyl)-1-hepten-6-yne can be converted into a cyclopentenone via carbonylation of zirconabicyclo intermediate (Eq. 4). ${ }^{2.10 b}$

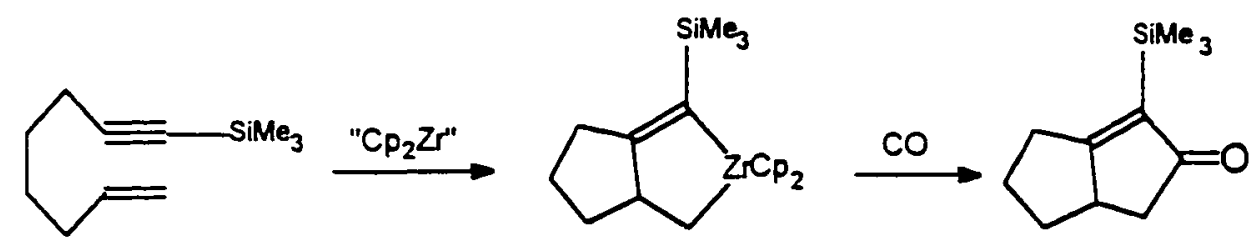

The zirconabicyclo intermediate can be converted into various other functionalzed compounds by iodination, oxidation, and other reactions which have been well studied by Negishi and et. $a l^{2,10}$ In 1994, Takahashi and co-workers ${ }^{10 b}$ studied the stereoselectivity of the cyclized products which were mediated by " $\mathrm{C} \mathrm{p}_{2} \mathrm{Zr}$ ". Cyclization of 1,4,7-trienes in 
the presence of stoichiometric Negishi reagent gives only cis isomers (>98\% stereoselectivity) (see Eq. 5). ${ }^{10 b}$<smiles>[R]C(CC=C)=C([R])CC=C</smiles><smiles>[R]C1=C([R])CC(C)C(C)C1</smiles>

$98 \%$

Erker ${ }^{11}$ was the pioneer who developed the chemistry of zirconocene complexes of unsaturated organic molecules. In 1979, he described the cross-coupling reaction of a zirconium benzyne complex trapped with ethylene to produce a metallacycle (Eq. 6). He also found the reversibility of this metallacyclization reaction, which was an important breakthrough for coupling reactions of diverse alkyne, alkene or heteroatom-containing organic complexes.<smiles>c1ccc(C(c2ccccc2)(c2ccccc2)c2ccccc2)cc1</smiles>
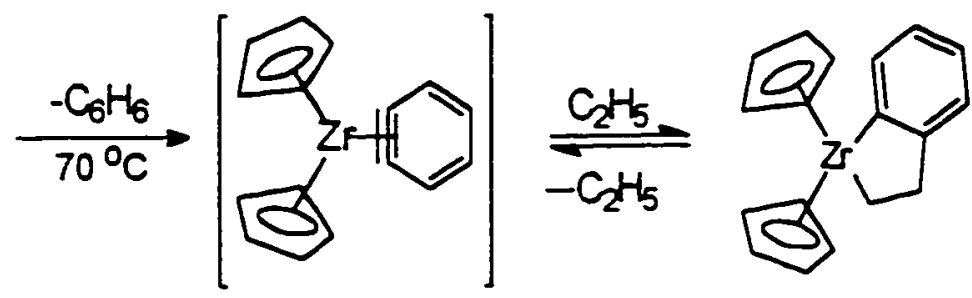

Buchwald and co-workers ${ }^{12}$ have developed Erker's chemistry by isolating a trimethylphosphine adduct of a zirconocene-benzyne (complex $\mathbf{A}$ in Scheme 4) and a zirconocene-cyclohexyne complex (complex B). While Erker's in situ generated benzyne 
intermediate does not react with aldehydes and ketones, Buchwald's isolated complexes (structures A and B in Scheme 4) undergo clean high-yield reactions.

\section{Scheme 4.}

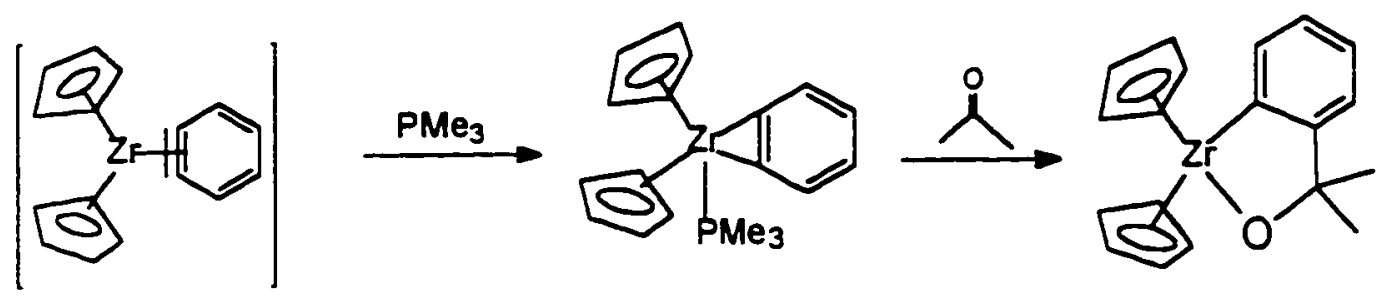

A

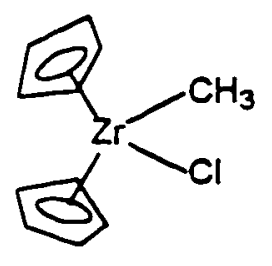<smiles>CC1CCCCC1C</smiles>

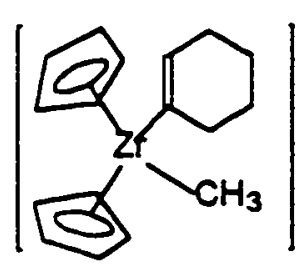

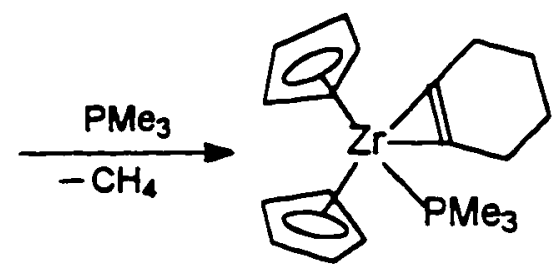

B<smiles>[B][CH]C(C)=O</smiles><smiles></smiles>

In the last two decades, complexes containing the $\left[\mathrm{C}_{2} \mathrm{Zr}\right]$ moiety have dominated organozirconium reagent use in organic synthesis. In the meantime, relatively few 
attempts have been made to employ non-cyclopentadienyl zirconium species in organic synthesis. One strategy is the use of aryloxide and alkoxide ligands; ${ }^{14 .}{ }^{19}$ however, the reactivity of zirconium alkoxide and aryloxide complexes for organic synthesis has been much less studied. After a few early reports about zirconium alkoxides (see Table 1), ${ }^{13}$ no reports have since appeared about their development for organic synthesis except $R$ $\mathrm{Zr}\left(\mathrm{OCH}_{2} \mathrm{CH}_{2} \mathrm{CH}_{2} \mathrm{CH}_{3}\right)_{3}$ as alkylating reagents (see below).

Rothwell and co-workers ${ }^{14}$ have isolated a series of bulky aryloxy (2,6-di-tertbutylphenoxide) zirconium species and studied their structural characteristics for $\mathrm{C}-\mathrm{H}$ bond activation. For example, the reaction of two equiv. of 2,6-di-tert-butylphenol (HOAr') with tetrabenzylzirconium, $\mathrm{Zr}\left(\mathrm{CH}_{2} \mathrm{Ph}\right)_{4}$, gives the substitution of two benzyl groups with the elimination of toluene. At $120^{\circ} \mathrm{C}$ in toluene solvent, the complex $\mathbf{A}$ (in Scheme 5) is formed with cleavage of the C-H bond of a tert-butyl group.

Table 1. The general properties of selected zirconium alkoxides. Complex Comments: Synthesis, Characterization $\mathrm{Zr}\left(\mathrm{OC}_{2} \mathrm{H}_{5}\right)_{4}$ From $\mathrm{Cp}_{2} \mathrm{ZrCl}_{2}, \mathrm{Zr}(\mathrm{Ph})_{2}\left(\mathrm{Et}_{2} \mathrm{O}\right)_{2}$, or $\mathrm{ZrCl}$ white crystals by sublimation at $165^{\circ} \mathrm{C}$. $\mathrm{Zr}\left(\mathrm{OC}_{3} \mathrm{H}_{7}\right)_{4} \quad$ From $\mathrm{Cp}_{2} \mathrm{ZrCl}_{2}$ or $\mathrm{ZrCl}_{4}$; white crystal by sublimation $\mathrm{Zr}\left(\mathrm{OC}_{4} \mathrm{H}_{9}\right)_{4} \quad$ From $\mathrm{ZrCl}$; colorless volatile liquid, burning with a yellow flame. 


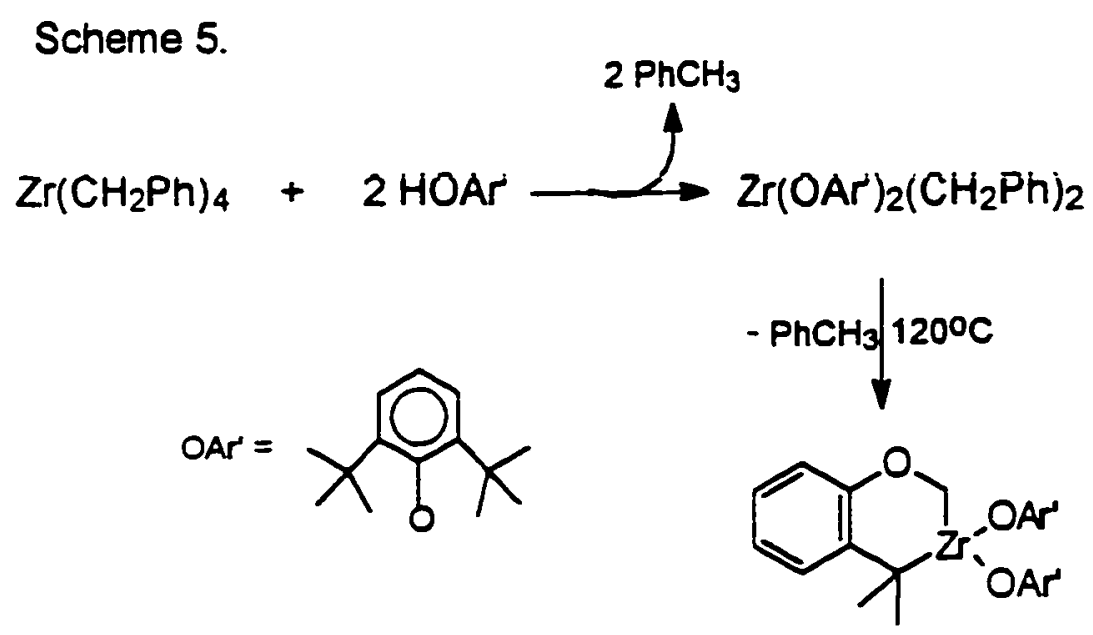

A

Wolczanski and co-workers ${ }^{15}$ have shown that alcoholsis of $\mathrm{Zr}\left(\mathrm{CH}_{2} \mathrm{Ph}\right)_{4}$ with tritert-butylmethanol leads to $\mathrm{Zr}($ tritox $)\left(\mathrm{CH}_{2} \mathrm{Ph}\right)_{3}\left(\right.$ tritox $\left.=\left(\left(\mathrm{CH}_{3}\right)_{3} \mathrm{C}\right)_{3} \mathrm{CO}^{-}\right)$and 1 equiv. of toluene (Eq. 7). Although these bulky alkoxy zirconium complexes have not been

$$
\begin{array}{ll}
(\text { tritox }) \mathrm{E}+\mathrm{Zr}\left(\mathrm{CH}_{2} \mathrm{Ph}\right)_{4} & \longrightarrow \mathrm{Zr} \text { (tritox })\left(\mathrm{CH}_{2} \mathrm{Ph}\right)_{3}+\mathrm{PhCH}_{2} \mathrm{E} \\
\mathrm{E}=\mathrm{H}, \mathrm{D} &
\end{array}
$$

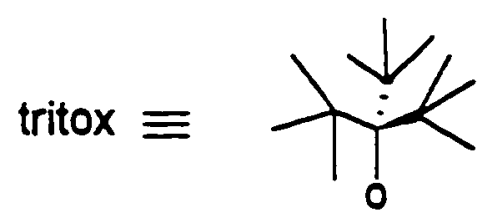

applied to organic synthesis, compararisons of the dioxygen reactivity of the complexes (tritox) ${ }_{2} \mathrm{Zr}\left(\mathrm{CH}_{3}\right)_{2}$ and $\mathrm{Cp}_{2} \mathrm{Zr}\left(\mathrm{CH}_{3}\right)_{2}{ }^{15 b}$ may give insights into the nature of zirconium alkoxide complexes in which alkoxide ligands give the metal more electrophilic metal character than the $\mathrm{Cp}$ ligand. The treatment of $\mathrm{Cp}_{2} \mathrm{Zr}\left(\mathrm{CH}_{3}\right)_{2}$ with 1 atm of $\mathrm{O}_{2}$ leads to 
formation of $\mathrm{Cp}_{2} \mathrm{Zr}\left(\mathrm{OCH}_{3}\right)_{2}$ over a 48-h period at $25^{\circ} \mathrm{C}$; however, (tritox $)_{2} \mathrm{Zr}\left(\mathrm{CH}_{3}\right)_{2}$ reacts with $\mathrm{O}_{2}$ at $-78^{\circ} \mathrm{C}$ within 5 min. resulting in (tritox) ${ }_{2} \mathrm{Zr}\left(\mathrm{OCH}_{3}\right)_{2}$.

Although alkyl or alkenylzirconocene complexes are quite inert toward aldehydes and ketones, organotitanium and zirconium alkoxide reagents, developed by Reet ${ }^{16}$ and Seebach, ${ }^{17}$ react with aldehydes and ketones with chemo-, regio-, and stereo-selectivities. Reetz and coworkers ${ }^{16}$ have demonstrated alkylation of a wide range of ketones and aldehydes with various alkyltitanium(IV) reagents $\left(\mathrm{RTiX}_{3}\right.$ or $\mathrm{R}_{2} \mathrm{TiX}_{2}, \mathrm{X}=\mathrm{Cl}, \mathrm{OR}$, and $\mathrm{NEt}_{2}$ ). With much work devoted to the development of efficient organotitanium reagents, impressive results have been obtained with alkyltriisopropoxytitanium ( $\mathrm{R}-\mathrm{Ti}\left(\mathrm{OCH}\left(\mathrm{CH}_{3}\right)_{2}\right)_{3}, \mathrm{R}=\mathrm{CH}_{3}$ or $\left.\mathrm{Ph}\right)$ and alkyltriphenoxytitanium $\left(\mathrm{RTi}(\mathrm{OPh})_{3}\right)$, leading to alkylation products with high selectivities. Recently, these workers have tested a number

Scheme 6.

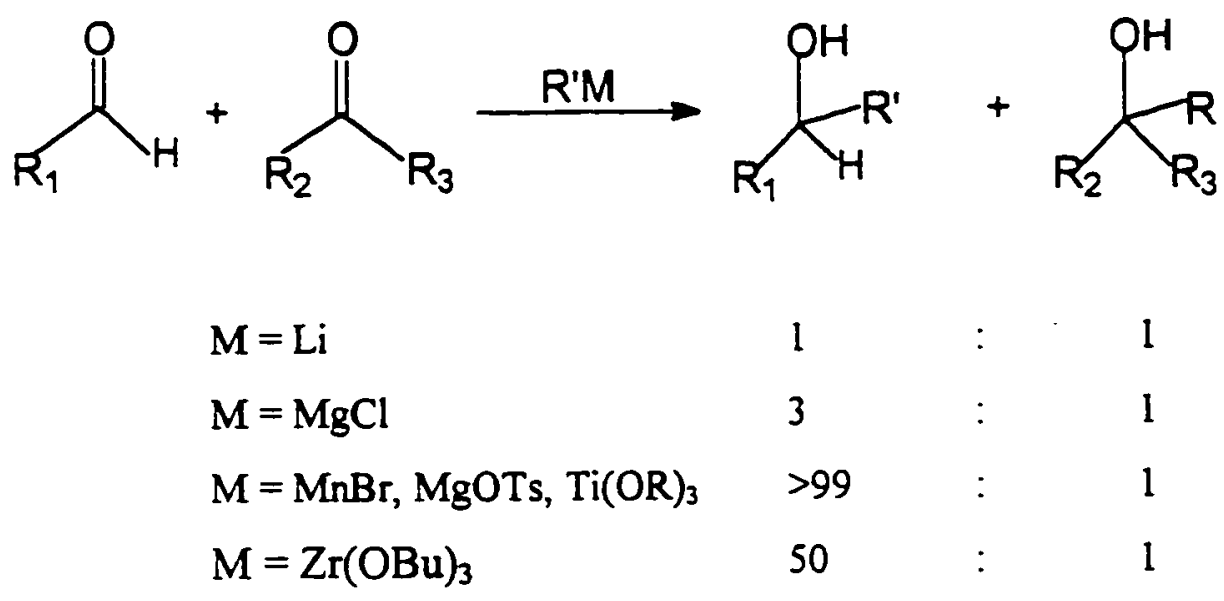


of other organometals such as organomaganese and organocerium reagents, as well as classical Grignard reagents $\mathrm{RMgL}(\mathrm{L}=$ tosylate, carboxylate, etc. $){ }^{\mathrm{l} 6 \mathrm{~b} . \mathrm{c}}$ These reagents react aldehyde-selectively in the presence of ketones (Scheme 6). Reactions conducted with the readily enolized ketone, $\alpha$-tetralone (Scheme 7), show that

Scheme 7.<smiles>O=C1CCCc2ccccc21</smiles>

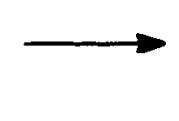

$\mathrm{CH}_{3} \mathrm{Ti}(\mathrm{OCHMe})_{3}$ $\mathrm{CH}_{3} \mathrm{Zr}(\mathrm{OBu})_{3}$<smiles>COC1(C)CCCc2ccccc21</smiles>
50 90<smiles>COC1=CCCc2ccccc21</smiles>

50

10

$\mathrm{CH}_{3} \mathrm{Zr}\left(\mathrm{OCH}_{2} \mathrm{CH}_{2} \mathrm{CH}_{2} \mathrm{CH}_{3}\right)_{3}$ is less basic than the titanium analog $\mathrm{CH}_{3} \mathrm{Ti}\left(\mathrm{OCH}\left(\mathrm{CH}_{3}\right)_{2}\right)_{3}$. The "ate" complex, $\mathrm{Li}\left[\mathrm{CH}_{3} \mathrm{Ti}\left(\mathrm{OCH}\left(\mathrm{CH}_{3}\right)_{2}\right)_{4}\right]$, appears to be most basic: when it reacts with acetophenone, the ketone is recovered, after vigorous methane gas evolution. ${ }^{16 \mathrm{~m}} 17 \mathrm{~b}$

Recently, we reported ${ }^{18}$ the alkylation of carbonyl compounds by zirconocene alkyls in the presence of alkoxide bases (Scheme 8). Possible intermediates in this process are anionic zirconium species ("ate" complexes). These in situ generated "ate" intermediates can alkylate (nucleophilic addition) non-enolizable aldehydes and ketones. However, there was no alkylation of enolizable ketones, such as cyclohexanone and 
Scheme 8.

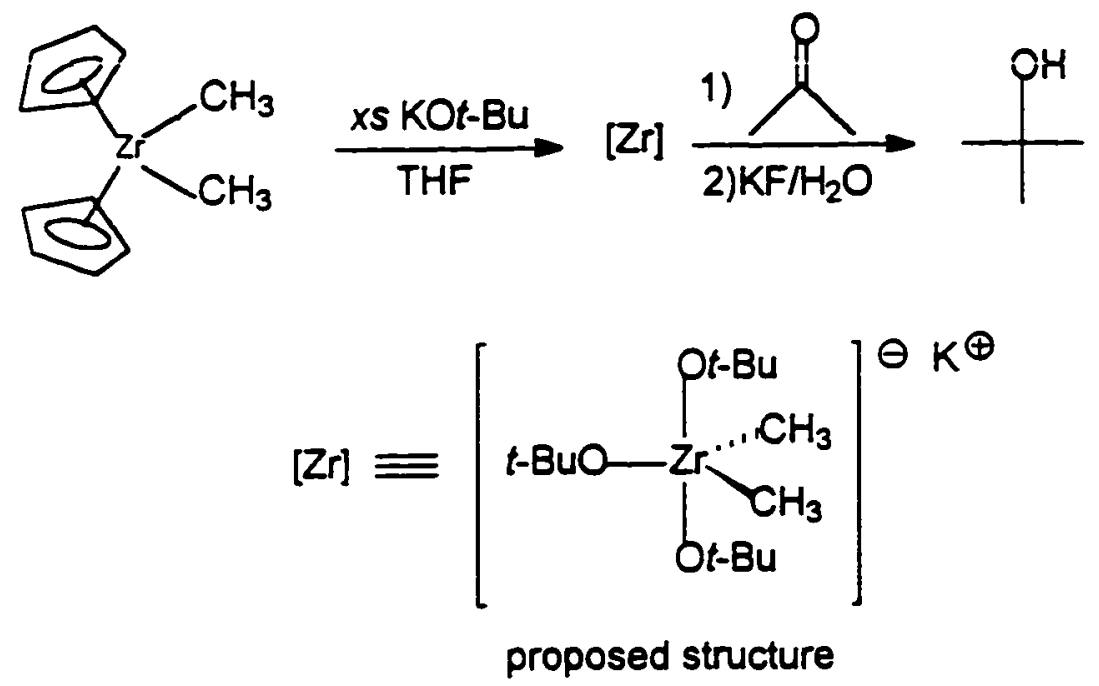

acetophenone. The reaction was further studied using benzaldehyde vs. benzophenone competition reactions. These selectivity data are summarized in Table 2. Because of lower selectivity in the competition reaction than that of the neutral Seebach reagent, $\mathrm{CH}_{3} \mathrm{Zr}\left(\mathrm{OCH}_{2} \mathrm{CH}_{2} \mathrm{CH}_{2} \mathrm{CH}_{3}\right)_{3}$, the zirconium "ate" intermediate was suggested. Lower selectivity of "ate" complexes was also observed by Reetz for the titanium derivates. ${ }^{16}$ The proposed zirconium "ate" complex (Scheme 8) from reaction of $\mathrm{Cp}_{2} \mathrm{Zr}\left(\mathrm{CH}_{3}\right)_{2}$ with 4 equivalents of $\mathrm{KO} t$-Bu was characterized in situ by NMR. Selective ${ }^{1} \mathrm{H}$ and ${ }^{13} \mathrm{C} N M R$ data are given in Table 3. The ${ }^{1} \mathrm{H}$ chemical shift of the methyl group in the $[\mathrm{Zr}]$ intermediate is positioned at $-1.07 \mathrm{ppm}$ upfield from TMS. It is further upfield than parent $\mathrm{Cp}_{2} \mathrm{Zr}\left(\mathrm{CH}_{3}\right)_{2}$ and other known methylalkoxidezirconium complexes. This upfield shifting is consistent with an electron-rich anionic complex. 
Table 2. Comparison of the selectivity in the competition reaction from the equimolar mixture of benzaldehyde and bezophenone.

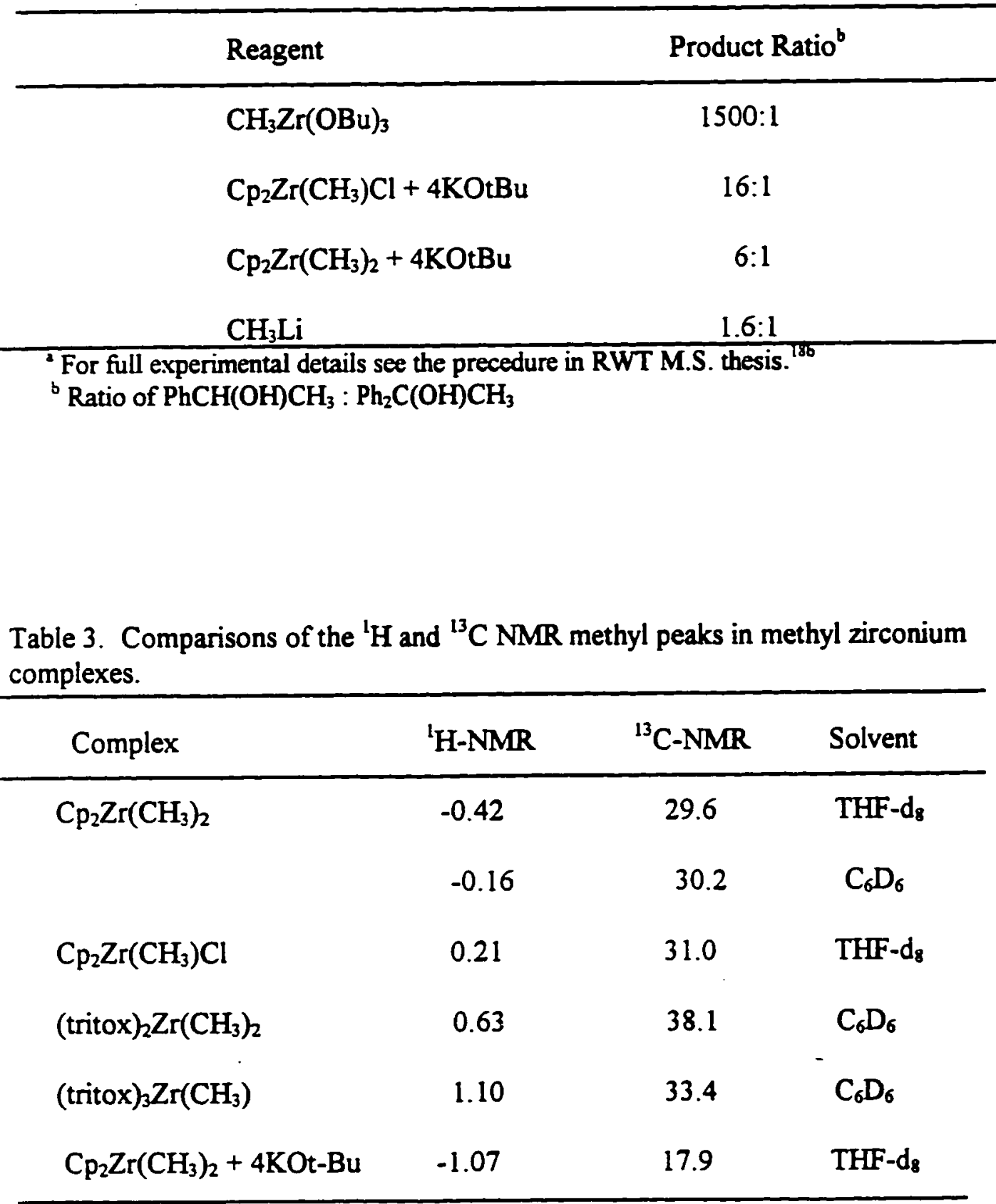




\section{References}

1. Schwartz, J.; Labinger, J. A. Angew. Chem. Int. Ed. Engl. 1976, 15, 333.

2. For reviews see: (a) Negishi, E.; Takahashi, T. Acc. Chem. Res. 1994, 27, 124. (b)

Negishi, E.; Takahashi, T. Synthesis, 1988, 1-19. (c) Buchwald, S. L.; Nielsen, R. B.

Chem. Rev. 1988, 88, 1047.

3. Crabtree, R. H. The Organometallic Chemistry of the Transition Metals, John Wiley \& Sons, New York, 1993, 2nd Ed., pp57-58.

4. (a) Wailes, P. C.; Weigold, H; Bell, A. P. J. Organomet. Chem. 1972, 34, 155. (b) Samuel, E.; Rausch, M. D.; J. Amer. Chem. Soc. 1973, 95, 6263.

5. Gambaro,S.; Strologo, S.; Florian, C.; Chiesi-Villa, A.; Guastin, C. Inorg. Chem. 1985, 24,654 .

6. (a) Kautzner, B.; Wailes, P. C.; Weigold, H. Chem. Commun. 1969, 1105. (b) Wailes, P. C.; Weigold, H. J. Organomet. Chem. 1970, 24, 405.

7. (a) Hart, D. W.; Blackburn, T. F.; Schwartz, J. J. Amer. Chem. Soc. 1975, 97, 679. (b) Schwartz, J. Pure Appl. Chem. 1980, 52, 733. (c) Hart, D. W.; Schwartz, J. J. Amer. Chem. Soc. 1974, 96, 8115.

8. Wipf, P.; Xu, W.; Smitrovich, J. H.; Lehmann, R.; Venanzi, L. M. Tetrahedron 1994, 50, 1935.

9. (a) Suzuki, K.; Hasegawa, T.; Imai, T.; Maeta, H.; Ohba, S. Tetrahedron 1995, 51 , 4483. (b) Hideki, M.; Suzuki, K. Tetrahedron Lett. 1992, 33, 5969. (c) Hideki, M.; Suzuki, K.; Hasegawa, T. Synlett 1993, 341.

10. (a) Takahashi, T.; Kotora, M.; Kasai, K. J. Chem. Soc., Chem. Commun. 1994, 2693. (b) Negishi, E.; Holmea, S. J.; Tour, J. M.; Miller, J. A.; Cedebraum, F. G.; Swanson, D. R.; Takahashi, T. J. Amer. Chem. Soc. 1989, III, 3336. (c) Kemp, M. L.; Whity, R. J.; Coote, S. J. Synlett. 1994, 451. (d) Uesaka, N.; Mori, M.; Okamura, K.; Date, J. J. Org. Chem. 1994, 59, 4542. (e) Gordon, G. J.; Whithy, R. J. Synlett, 1995, 77. (f) Takahashi, T.; Taka, S.; Nitto, Y.; Saburi, M.; Rousset, C. J.; Negishi, E-J. J. Amer. Chem. Soc. 1991, 113, 6266.

11. Erker, G.; Kropp, K. J. Amer. Chem. Soc. 1979, 101, 3659. 
12. (a) Broene, R. D.; Buchwald, S. L. Science, 1993, 261, 1696. (b) Buchwald, S. L.; Lum, R. T.; Dewan, J. C. J. Amer. Chem. Soc. 1986, 108, 7441.

13. (a) Bradley, D. C.; Wardlaw, W. J. Chem. Soc. 1951, 280. (b) Gray, D. R.; Brubaker, C. H. Inorg. Chem. 1971, IO, 2143. (c) Koschmieder, S. U.; Wilkinson, G. Polyhedron 1991, 10, 135. (d) Razuvaev, G. A.; Latyaeva, V. N.; Vishinskaya, L. I.; Rabinovitch, A. M. J. Organomet. Chem. 1973, 49, 441.

14. (a) Rothwell, I. P. Acc. Chem. Res. 1988, 21 , 153. (b) Latesky, S. L.; McMullen, A. K.; Rothwell, I. P.; Huffman, J. C. J. Amer. Chem. Soc. 1985, 107, 5981.

15. (a) Lubben, T. V.; Wolczanski, P. T. J. Amer. Chem. Soc. 1987, 109, 424. (b) Lubben, T. V.; Wolczanski, P. T.; Van Duyne, G. D. Organometallics 1984, 3, 977.

16. (a) Reetz, M. T. In Topics in Current Chemistry; Boschke, F. L., Ed.; Springer: Berlin, 1982; Vol. 106, pp 3-54. (b) Reetz, M. T. Pure Appl. Chem. 1985, 57, 17811788. (c) Reetz, M. T. Organotitanium Reagents in Organic Synthesis; Springer: Berlin, 1986. (d) Reetz, M. T.; Steinbach, R.; Westermann, J.; Peter, R. Angew. Chem., Int. Ed. Engl., 1980, 19, 1011.

17. (a) Weidmann, B.; Seebach, D. Angew. Chem. Int. Ed. Engl. 1983, 22, 31-41; Angew. Chem. 1983, 95, 12-26. (b) Seebach, D.; Weidmann, B.; Wilder, L. In Modern Synthetic Methods; Scheffold, R., Ed.; Salle: Frankfurt/Sauerlander: Aarau, 1983; Vol. 3, p217. (c) Seebach, D.; Beck, A. K.; Schiess, M.; Wildler, L.; Wonnacott, A. Pure Appl. Chem. 1983, 55, 1807-1822.

18. (a) Larson, A. L.; Baker, D.L.; Towne, R. W.; Straus, D. A. Teteahedron Lett. 1991, 32, 5893. (b) Towne, R. W. M. S. Thesis, San Jose State University, 1994. 


\section{Chapter II \\ Preparation of Anionic Alkoxyalkylzirconium Complexes Introduction}

Only a few well-characterized anionic zirconium(IV) complexes have been reported. The first of these were the anionic ketene zirconocene complexes by Grubbs group, ${ }^{1}$ prepared as shown in Scheme 1. When deprotonation of $\mathrm{Cp} 2 \mathrm{Zr}\left(\mathrm{COCH}_{3}\right) \mathrm{CH}_{3}$ with $\mathrm{NaN}(\mathrm{TMS})_{2}\left(\mathrm{TMS}=\mathrm{Si}\left(\mathrm{CH}_{3}\right)_{3}\right)$ occurs in $\mathrm{Et}_{2} \mathrm{O}$ at $-30^{\circ} \mathrm{C}$, the anionic complex $\mathrm{Na}\left(\mathrm{Et}_{2} \mathrm{O}\right)\left[\mathrm{Cp}_{2} \mathrm{Zr}\left(\mathrm{COCH}_{2}\right) \mathrm{CH}_{3}\right]$ precipitates as a pyrophoric white powder. This salt has been characterized by ${ }^{1} \mathrm{H}$ and ${ }^{13} \mathrm{C} N M R, \mathbb{R}$, and elemental analysis. Reaction of $\mathrm{Na}\left(\mathrm{Et}_{2} \mathrm{O}\right)\left[\mathrm{Cp}_{2} \mathrm{Zr}\left(\mathrm{COCH}_{2}\right) \mathrm{CH}_{3}\right]$ with $\mathrm{CH}_{3} \mathrm{I}$ gives the unsymmetrical alkyl acyl complex, $\mathrm{Cp}_{2} \mathrm{Zr}\left(\mathrm{COCH}_{2} \mathrm{CH}_{3}\right) \mathrm{CH}_{3}$, at room temperature in THF.

Scheme 1.

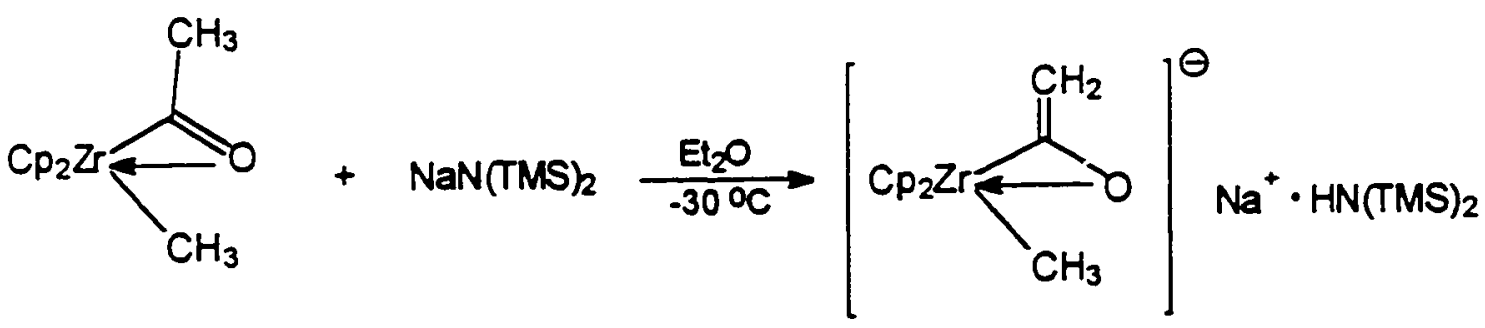

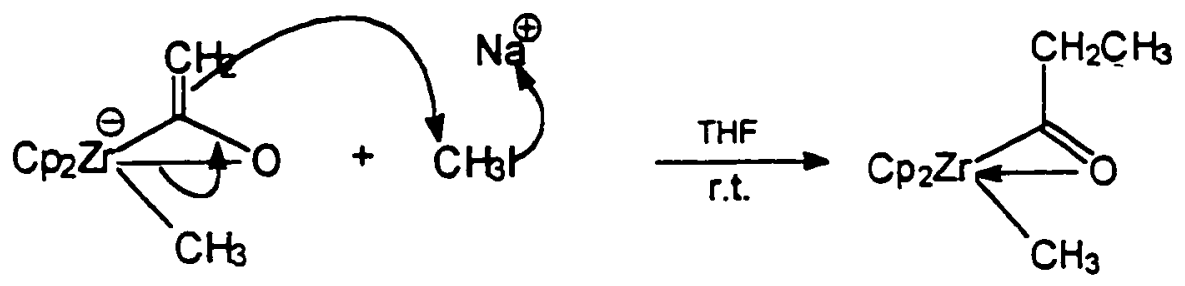


More recently, the anionic series of zirconocene $\left(\eta^{2}\right.$-aldehyde) complexes (zirconaoxiranes) has been reported. ${ }^{2}$ These complexes arise from the reaction of methyllithium with $\alpha$-stannylalkoxide zirconocene complexes (see Eq. 1). A single crystal of the complex $\mathbf{A}$ was obtained and an X-ray structural study was carried out. It exists as a dimer through bridging of the two aldehyde oxygen atoms by lithium counterions. Nonequivalent cyclopentadienyl and $\mathrm{Zr}$-methyl groups were also observed in NMR analysis. The authors further report ${ }^{2 b}$ that reaction of the anionic zirconaoxiranes with simple metal carbonyls gives anionic heterobimetallic complexes having a new carboncarbon bond.

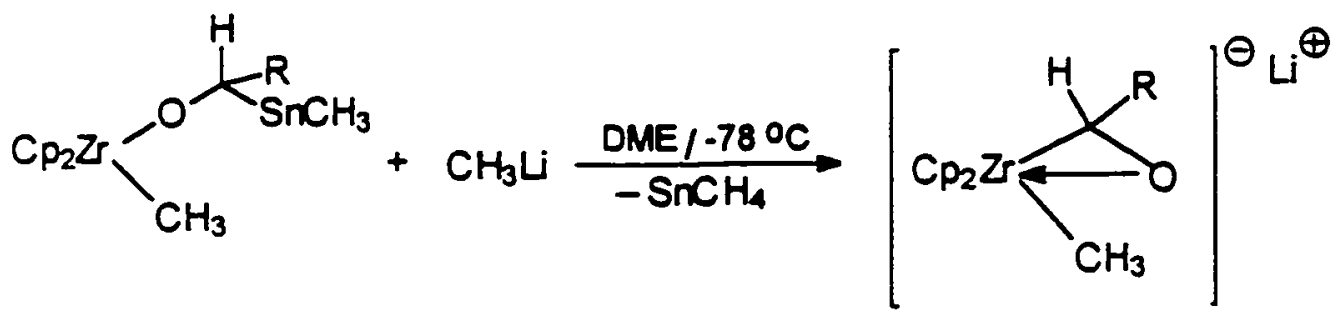

The reaction of $\mathrm{Cp}_{2}^{*} \mathrm{ZrCl}_{2}\left(\mathrm{Cp}^{*}=\eta^{5}-\mathrm{C}_{5}\left(\mathrm{CH}_{3}\right)_{5}\right)$ with $\mathrm{KH}$ in $\mathrm{THF}$ has been reported to yield the first anionic zirconocene hydride, $\left[\mathrm{K}(\mathrm{THF})_{2}\right]\left[\mathrm{Cp}_{2}^{*} \mathrm{ZrH}_{3}\right]^{3}$ Characterization of this complex was achieved by ${ }^{1} \mathrm{H}$ and ${ }^{13} \mathrm{C}$ NMR data with supporting $\mathrm{X}$-ray crystallography. In the ${ }^{1} \mathrm{H}$ NMR spectrum, for example, three hydrides were in two 
environments $(\delta 1.70(d)$ and $\delta-0.92(t))$ in a ratio of $1: 2$ consistent with a dimeric complex. The dimeric nature of this zirconium hydride was confirmed in the solid state by X-ray diffraction.

Reaction of $\mathrm{Cp}_{2} \mathrm{ZrCl}_{2}$ with 3 equivalents of $\mathrm{LiC} \equiv \mathrm{CPh}$ gives ( $\mathrm{Z}$ )-1,4-diphenyl-1buten-3-yne after quenching with $3 \mathrm{~N} \mathrm{HCl}$. Formation of an anionic zirconocene complex as an intermediate in this process has been proposed by the Negishi group. ${ }^{4}$ Formation of the in situ generated anionic alkynylzirconocene (complex A or B in Scheme 2) has been supported by preparation of complex $C$ by reaction of $C p_{2} \operatorname{Zr}(C \equiv C R)_{2}$ with $L i P h$.

Although pure complex $\mathbf{C}$ was not isolated, quenching with $3 \mathrm{~N} \mathrm{HCl}$ provides (Z)-stilbene ( $85 \%$ GLC yield for $\mathrm{R}=\mathrm{Ph}$ ). This result is consistent with the proposed intermediary formation of an anionic alkynylzirconocene.

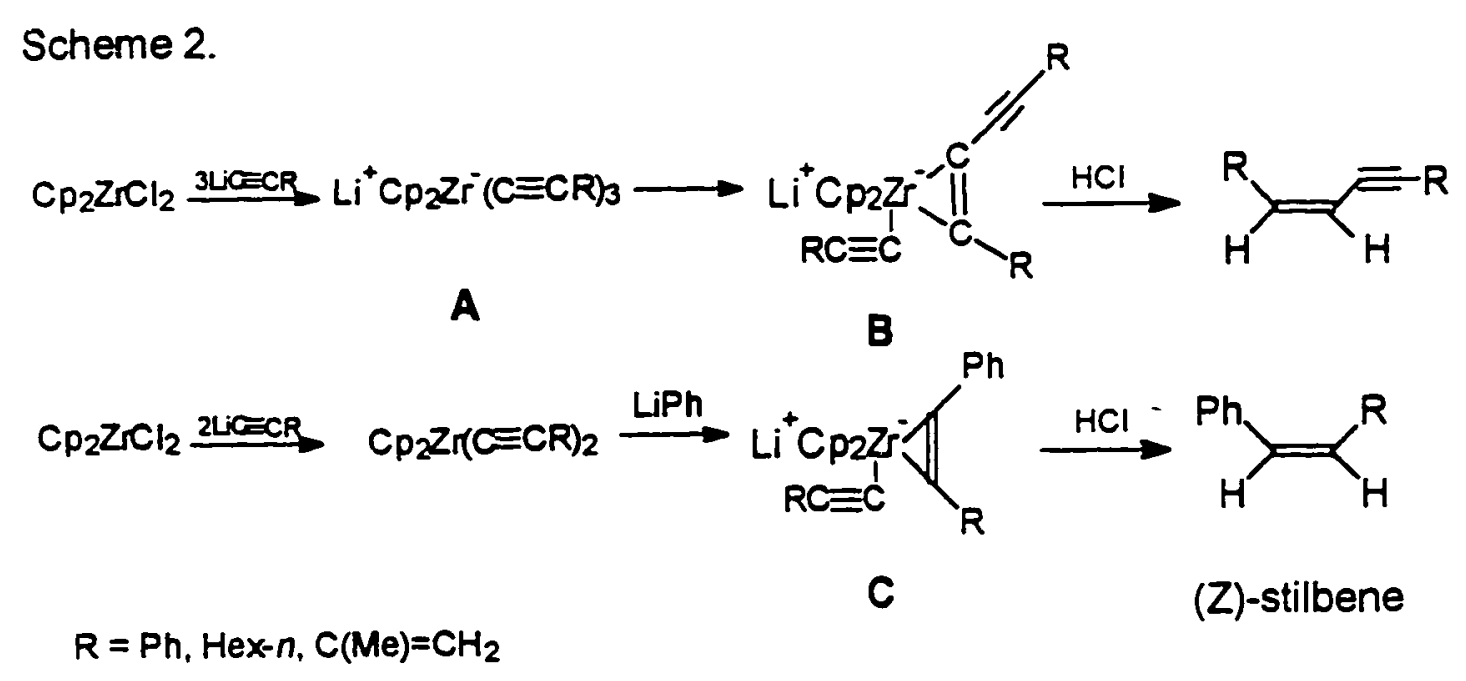


As briefly described in Chapter 1, Reetz and Seebach have developed anionic alkyl (or allyl)titanium alkoxide complexes as alkylating (or allylating) reagents in organic synthesis. ${ }^{5}$ For example, the allyl "ate" complexes are prepared in situ from the reaction of $\mathrm{Ti}\left(\mathrm{OCH}\left(\mathrm{CH}_{3}\right)_{2}\right)_{4}$ (or $\mathrm{Ti}\left(\mathrm{N}\left(\mathrm{CH}_{3}\right)_{2}\right)_{4}$ for the amino "ate" complex) with allylmagnesium chloride. Since spectral and structural information is not available, they speculated that formula $\mathbf{A}, \mathbf{B}$, and $\mathbf{C}$ in Scheme 3 are regarded as formal representations of titanium "ate" complexes. However, there is no research about zirconium "ate" complexes as organic reagents. Reactivities will be discussed further in Chapter 3 of this thesis.

\section{Scheme 3.}

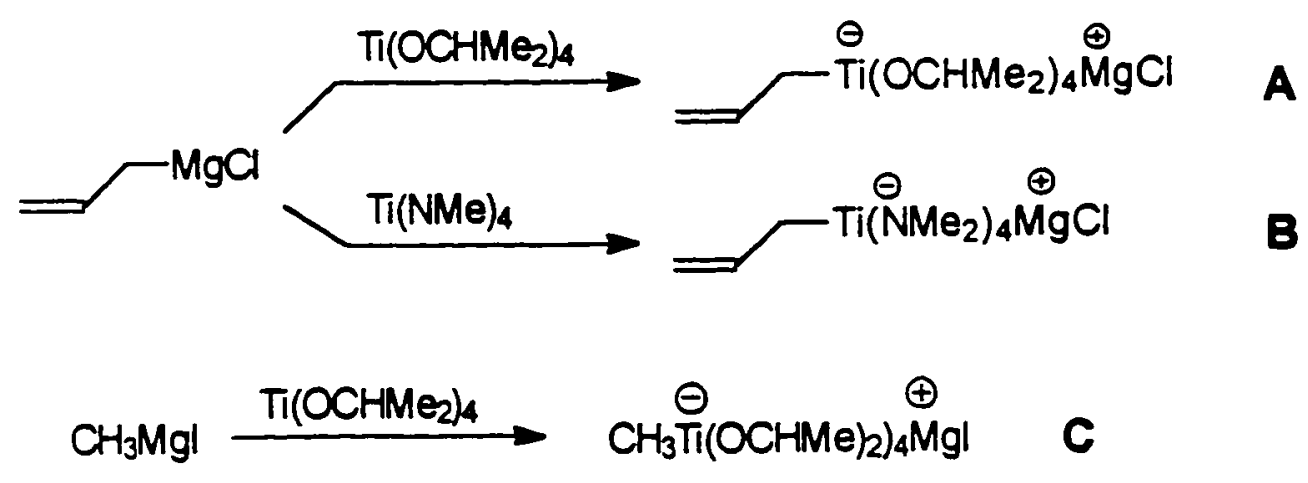

Herein we report the first example of an isolated alkylzirconium "ate" complex to afford a new type of alkylation reagent in organic synthesis. The attempted synthesis of anionic zirconium alkyl complexes, $\mathrm{K}\left[\mathrm{Zr}(\mathrm{OR})_{3}\left(\mathrm{R}^{\prime}\right)_{2}\right]\left(\mathrm{OR}=\mathrm{O} t-\mathrm{Bu} ; \mathrm{R}^{\prime}=\mathrm{CH}_{3}, \mathrm{Ph}\right.$, $\left.\mathrm{CH}_{2} \mathrm{Ph}\right)$ and $\mathrm{K}\left[\mathrm{Zr}\left(\mathrm{CH}_{2} \mathrm{Ph}\right)_{4}(\mathrm{Ot}-\mathrm{Bu})\right]$, have been carried out in an effort to develop new 
Grignard type reagents as well as to elucidate the $\mathrm{Cp}_{2} \mathrm{Zr}\left(\mathrm{CH}_{3}\right)_{2} / \mathrm{KO}$ - $\mathrm{Bu}$ alkylation mechanism.

\section{Results and Discussion}

\section{A. Synthesis and Spectroscopic Properties of $\mathrm{K}\left[(\mathrm{t}-\mathrm{BuO})_{3} \mathrm{Zr}\left(\mathrm{CH}_{3}\right)_{2}\right](1)$.}

A pyrophoric white powder, formulated as $\mathrm{K}\left[(t-\mathrm{BuO})_{3} \mathrm{Zr}\left(\mathrm{CH}_{3}\right)_{2}\right]$, has been isolated by reaction of $\mathrm{Cp}_{2} \mathrm{Zr}\left(\mathrm{CH}_{3}\right)_{2}$ with 3 equivalents of potassium tert-butoxide. The reaction is allowed to proceed for 1 hour in THF solvent at $-30^{\circ} \mathrm{C}$, followed by addition of hexane (or pentane) and filtration. The colorless filtrate is allowed to stand at $-50^{\circ} \mathrm{C}$ to further precipitate the crystalline $\mathrm{KCp}$ by-product. The supernatant is decanted and additional hexane is added at $-30{ }^{\circ} \mathrm{C}$ to precipitate 1 as a white solid complex (Eq. 2).

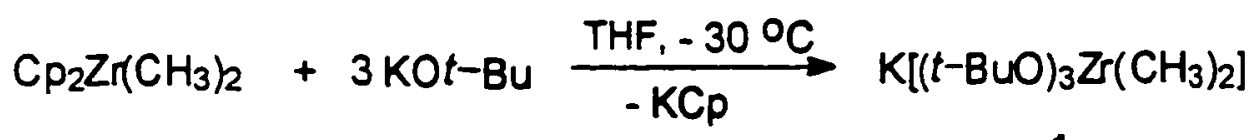

The white powder ignites rapidly when exposed to air, giving a black residue. Exposure to water leads to rapid gas evolution and formation of a white solid. It also reacted with $\mathrm{CH}_{3} \mathrm{CN}$ producing yellow powder and gas (see Scheme 4). We did not try characterization of these products but in our previous report, ${ }^{6}$ methane gas was confirmed upon the reaction of $\mathrm{CH}_{3} \mathrm{CN}$ with a mixture of $\mathrm{KO}$ - $\mathrm{Bu}$ and $\mathrm{Cp}_{2} \mathrm{Zr}\left(\mathrm{CH}_{3}\right)_{2}$. 
Scheme 4.

$$
\mathrm{K}\left[(t-\mathrm{BuO})_{3} \mathrm{Zr}\left(\mathrm{CH}_{3}\right)_{2}\right]+\left\{\begin{array}{l}
\mathrm{CH}_{3} \mathrm{CN} \longrightarrow \text { Yellow Powder + Gas } \\
\mathrm{H}_{2} \mathrm{O} \longrightarrow \text { White Powder + Gas } \\
\mathrm{O}_{2} \longrightarrow \text { Black Powder + Gas }
\end{array}\right.
$$

Complex 1 is indefinitely stable when stored under $\mathrm{N}_{2}$ or $\operatorname{Ar}\left(-20^{\circ} \mathrm{C}\right)$ and no significant decomposition of THF solutions is observed over a period of several months at $-20^{\circ} \mathrm{C}$. The complex is insoluble in hexane and pentane and moderately soluble in benzene, toluene, and ether. However, it decomposed to some extent in benzene, ether and toluene.

The anion, 1, was characterized principally with ${ }^{1} \mathrm{H}$ NMR and ${ }^{13} \mathrm{C}$ NMR (Table 1 and Figures 1, and 2), which are valuable for establishing the purity. From the spectral data, it is estimated that 1 contains $<1 \%$ of $\mathrm{KCp}$ and unknown impurities. In the ${ }^{1} \mathrm{H}$ NMR (Table 1 and Figure 1), the methyl resonance of this anion $(\delta=-0.57 \mathrm{ppm})$ is downfield compared to the in situ generated anion $(\delta=-1.07 \mathrm{ppm})^{6}$ and upfield from $\mathrm{Cp}_{2} \mathrm{Zr}\left(\mathrm{CH}_{3}\right)_{2}$ $(\delta=-0.42 \mathrm{ppm})$. The integrated ratio of $\mathrm{O}-\mathrm{C}\left(\mathrm{CH}_{3}\right)_{3}$ to $\mathrm{CH}_{3}$ is $5: 1$ which is slightly higher than that of the formulated anion (4.5:1) and there are some peaks near $\mathrm{O}-\mathrm{C}\left(\mathrm{CH}_{3}\right)_{3}(\delta=$ $1.27,1.32$ and $1.33 \mathrm{ppm})$ and small methyl peaks $(\delta=-1.1$ to $0.2 \mathrm{ppm})$. The ${ }^{13} \mathrm{C} N M R$ spectrum (Figure 2) of anion 1 also shows an unidentified peak $(\delta=33.8 \mathrm{ppm})$ in $\mathrm{O} t-\mathrm{Bu}$ region. It may be the result of decomposition by a small amount of adventitious water or 


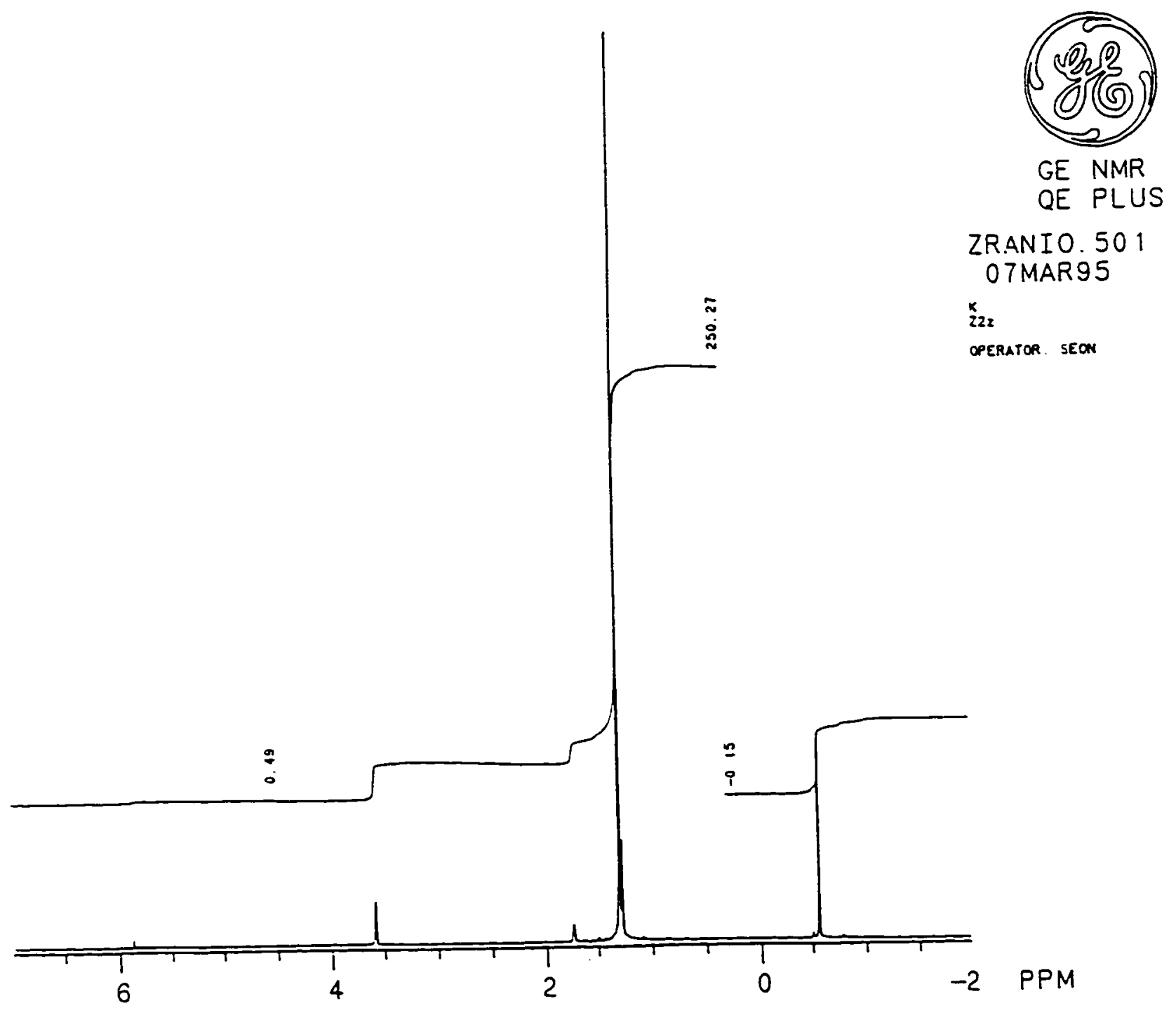

Figure 1. ' $\mathrm{H}$ NMR spectrum of $\mathrm{K}\left[(t-\mathrm{BuO})_{3} \mathrm{Zr}\left(\mathrm{CH}_{3}\right)_{2}\right]$ in THF-ds solution. The small resonance upfield at $5.83 \mathrm{ppm}$ is $\mathrm{KCp}$. 


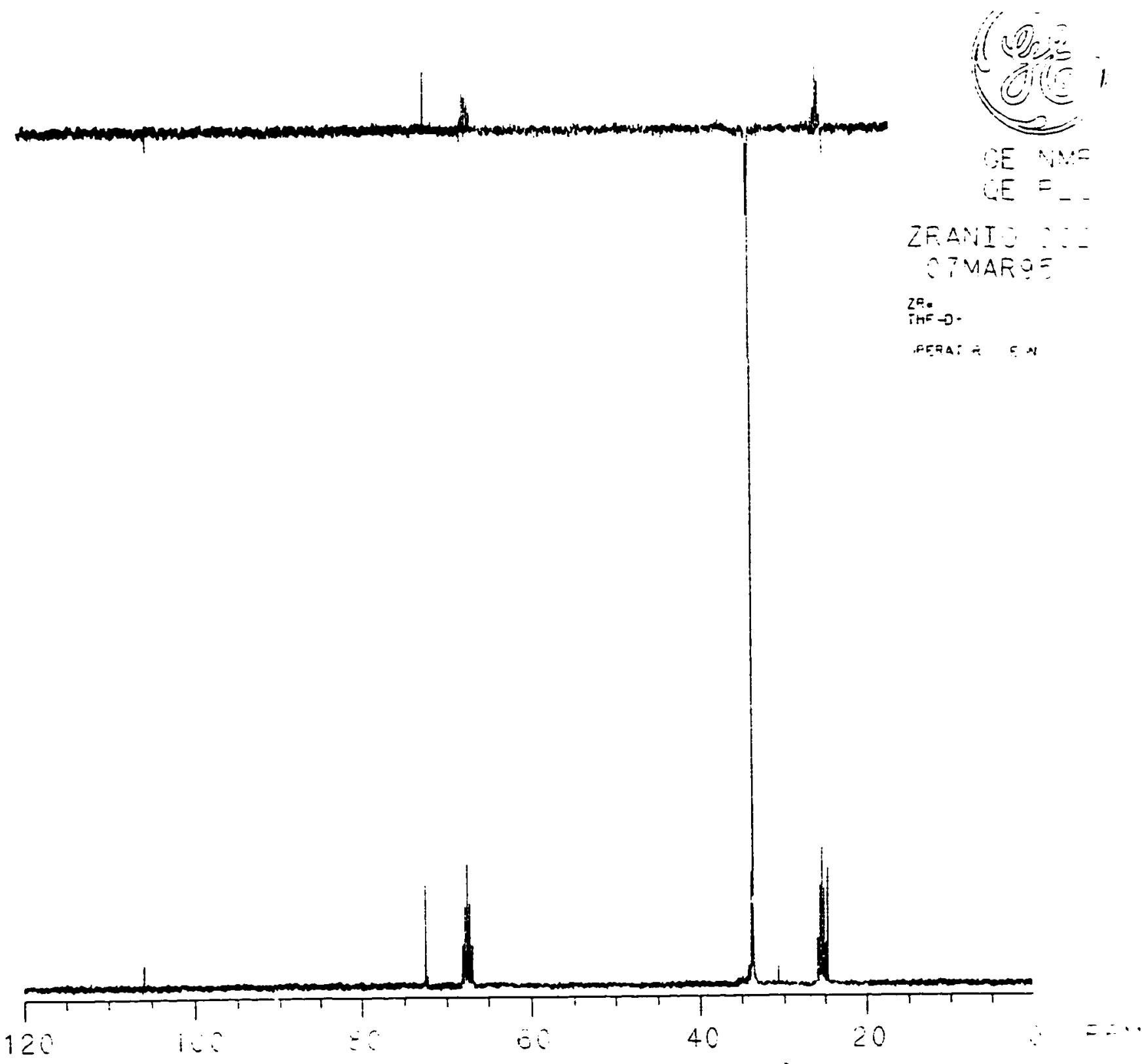

Figure $2 .{ }^{13} \mathrm{C} \mathrm{NMR}$ (with APT) spectrum of $\mathrm{K}\left[(t-\mathrm{BuO})_{3} \mathrm{Zr}\left(\mathrm{CH}_{3}\right)_{2}\right]$ in $\mathrm{THF}-d_{8}$ solution. The small resonance upfield at $109.3 \mathrm{ppm}$ is $\mathrm{KCp}$. 
Table 1. ${ }^{1} \mathrm{H}$ and ${ }^{13} \mathrm{C}$ NMR chemical shift data for various $\mathrm{O}-\mathrm{C}^{1}\left(\mathrm{C}^{2} \mathrm{H}_{3}\right)_{3}$ and $\mathrm{Zr}-\mathrm{CH}_{3}$ complexes in THF- $d_{8}$.

\begin{tabular}{|c|c|c|c|c|c|}
\hline \multirow[b]{2}{*}{ Compound } & \multicolumn{2}{|c|}{${ }^{\prime} \mathrm{H}$ NMR $(\delta, \mathrm{ppm})$} & \multicolumn{3}{|c|}{${ }^{13} \mathrm{C}$ NMR $(\delta, \mathrm{ppm})$} \\
\hline & $\mathrm{O}-\mathrm{C}\left(\mathrm{CH}_{3}\right)_{3}$ & $\mathrm{Zr}-\mathrm{CH}_{3}$ & $\mathrm{C}^{\prime}$ & $\mathrm{C}^{2}$ & $\mathrm{Zr}-\mathrm{CH}_{3}$ \\
\hline $\mathrm{KO}-\mathrm{C}\left(\mathrm{CH}_{3}\right)_{3}$ & 0.98 & & 67.2 & 37.4 & \\
\hline $\mathrm{Cp} 2 \mathrm{Zr}\left(\mathrm{CH}_{3}\right)_{2}$ & & -0.42 & & & 29.6 \\
\hline $\mathrm{K}\left[(t-\mathrm{BuO})_{3} \mathrm{Zr}\left(\mathrm{CH}_{3}\right)_{2}\right](1)$ & 1.29 & -0.57 & 72.5 & 33.6 & 24.5 \\
\hline $\mathrm{CP}=\mathrm{Zr}\left(\mathrm{CH}_{3}\right)_{2}+4 \mathrm{KO}-\mathrm{C}\left(\mathrm{CH}_{3}\right)_{3}$ & $1.08,1.19$ & -1.07 & $69.9,71.9$ & $34.3,34.7$ & 17.9 \\
\hline
\end{tabular}

*Ref. 6.

adventitious water or oxygen, or it may arise from a dimeric species via bridging cations of the type $\mathrm{Zr}-\mathrm{O}-\mathrm{K}-\mathrm{O}-\mathrm{Zr}$. Although there are only rare examples of $\alpha$-hydrogen elimination in $d^{0}$ alkylzirconium complexes, an $\alpha$-abstraction may be related to one of impurities (Eq. 3), but the evidence of a methylidene zirconium does not clearly appear in ${ }^{1} \mathrm{H}$ and APT NMR spectra (see Figures $\mathrm{I}$ and 2). Unsatisfactory $\mathrm{C}$ and $\mathrm{H}$ analysis were obtained on this anion. One elemental analysis calculated for $\mathrm{K}\left[(t-\mathrm{BuO})_{3} \mathrm{Zr}\left(\mathrm{CH}_{3}\right)_{2}\right]$, $\mathrm{C}_{14} \mathrm{H}_{33} \mathrm{O}_{3} \mathrm{ZrK}: \mathrm{C}, 44.28 ; \mathrm{H}, 8.76$. Found: $\mathrm{C}, 42.04 ; \mathrm{H}, 8.60$. This may be the result of the extreme sensitivity to oxygen and moisture or $\mathrm{KCp}$ impurities.

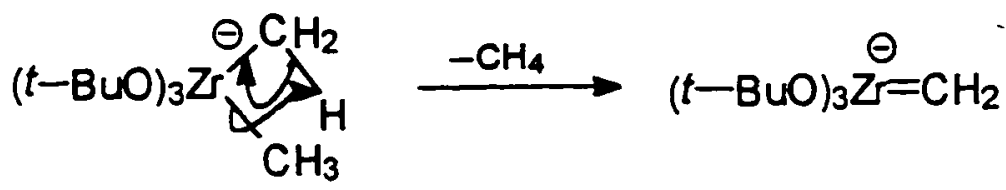


To better remove $\mathrm{KCp}$ and to help crystallization of product, we sought another bulky cation which may give different solubility between $\mathrm{MCp}$ and $\mathrm{M}\left[(t-\mathrm{BuO})_{3} \mathrm{Zr}\left(\mathrm{CH}_{3}\right)_{2}\right]$ $\left(M=K^{\top}(18-\right.$ crown-6), or PPN). However, the addition of 18-crown-6 ether or PPNCl $\left(\mathrm{PPN}=\mathrm{N}\left(\mathrm{P}\left(\mathrm{C}_{6} \mathrm{H}_{5}\right)_{3}\right)_{2}\right)$ to the $\mathrm{K}\left[(\mathrm{t}-\mathrm{BuO})_{3} \mathrm{Zr}\left(\mathrm{CH}_{3}\right)_{2}\right] / \mathrm{KCp}$ mixture results in the loss of the methyl peak in the complex ${ }^{1} \mathrm{H}$ NMR spectrum. In the literature, ${ }^{7}$ Atwood reported that $\mathrm{ZrCl}_{4}$ reacts with 18 -crown-6 in toluene/THF solution to form the ring opening product formulated as $\left[\mathrm{ZrCl}_{2}\left(\mathrm{OCH}_{2} \mathrm{CH}_{2}\right)_{5} \mathrm{OCH}_{2} \mathrm{CH}_{2} \mathrm{Cl}\right][\mathrm{ZrCl}$ (THF)].

\section{B. Other Attempted Reactions.}

1. Reaction of $\mathrm{Cp}_{2} \mathrm{ZrPh}_{2}$ with $4 \mathrm{KO}$-Bu. The reaction of $\mathrm{Cp}_{2} \mathrm{ZrPh}_{2}$ with 4 equivalents of $\mathrm{KO} t-\mathrm{Bu}$ in an NMR tube (THF- $\left.d_{6}\right)$ shows benzene, $\mathrm{KCp}$ and some new $\mathrm{O}$ $\mathrm{C}\left(\mathrm{CH}_{3}\right)_{3}$ peaks by NMR analysis. There is dramatic color change from purple to green to yellow over $60 \mathrm{~min}$. while it melts upon warming from $-198{ }^{\circ} \mathrm{C}$ to room temperature in the sealed NMR tube. The generation of benzene is supported by the well known diphenylzirconcene reaction of Erker. ${ }^{8}$ For example, even though there is no report about color changes, Scheme 6 in Chapter I describes formation of a benzyne intermediate, and thus the purple solution in the title reaction may result the formation of an analogous benzyne complex (Scheme 5). Several attempts to characterize this purple compound have failed because it is short-lived and unstable in THF at room temperature. The purple solid can be isolated in the reaction of $\mathrm{Cp}_{2} \mathrm{ZrPh}_{2}$ with $3 \mathrm{KO} t-\mathrm{Bu}$ in toluene at $-20^{\circ} \mathrm{C}$; 
however, it always decomposed in the NMR solvent at room temperature giving only solvent peaks in a yellow solution and brown precipitate.

\section{Scheme 5.}

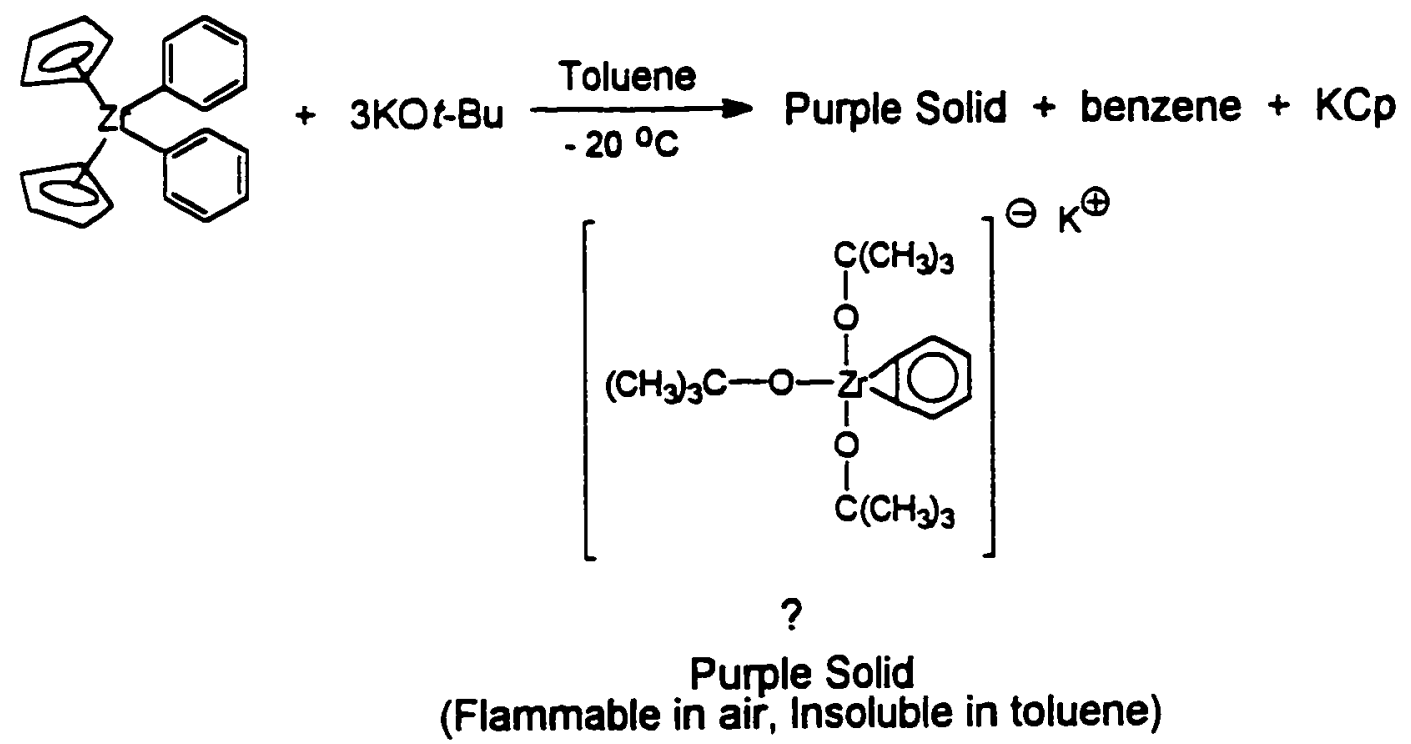

2. Reaction of $\mathrm{Cp}_{2} \mathrm{Zr}\left(\mathrm{CH}_{2} \mathrm{Ph}\right)_{2}$ with $4 \mathrm{KO}$-Bu. The reaction of potassium tertbutoxide ( 4 equivalents) with dibenzylzirconocene in an NMR tube (THF- $d_{8}$ ) gives unreacted base and some new $\mathrm{O}-\mathrm{C}\left(\mathrm{CH}_{3}\right)_{3}$ peaks, toluene peaks and a $\mathrm{KCp}$ peak. Although red powder (pyrophoric in air) can be isolated from the reaction of $\mathrm{Cp}_{2} \mathrm{Zr}\left(\mathrm{CH}_{2} \mathrm{Ph}\right)_{2}$ with $3 \mathrm{KOt}$-Bu in THF, the ${ }^{\mathrm{l}} \mathrm{H}$ NMR spectrum is too complex to be interpreted. 
We did not try further studies of red powder (and purple solid in reaction 1) and alkylations, because the observation of toluene in reaction 2 (or benzene in reaction 1) did not appear promising as a Grignard type reagent in organic synthesis.

3. Reaction of $\operatorname{Zr}\left(\mathrm{CH}_{2} \mathrm{Ph}\right)$, with $\mathrm{KO}$-Bu. Tetrabenzylzirconium reacted with 1 equivalent of $\mathrm{KOt}-\mathrm{Bu}\left(\mathrm{THF},-20^{\circ} \mathrm{C}\right.$ to room temperature) to give an orange solid upon addition of hexane. The product (orange fine powder) is extremely flammable in air. It is thermally unstable and will blacken at room temperature under $N_{2}$ after several hours. However, there is no change in NMR spectrum. The ${ }^{1} \mathrm{H}$ NMR spectrum appears inconsistent with the expected product, $\mathrm{K}\left[\left(\mathrm{C}_{6} \mathrm{H}_{5} \mathrm{CH}_{2}\right)_{4} \mathrm{Zr}\left(\mathrm{Ot}-\mathrm{C}\left(\mathrm{CH}_{3}\right)_{3}\right]\right.$ (Eq. 4).

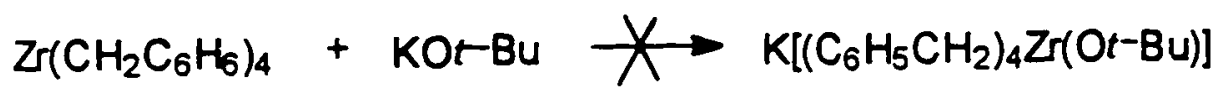

The ${ }^{1} \mathrm{H}$ NMR data for $\mathrm{KO} t-\mathrm{Bu},\left(\mathrm{C}_{6} \mathrm{H}_{5} \mathrm{CH}_{2}\right)_{4} \mathrm{Zr}$ and the product (Figure 3 ) are listed in Table 2. The benzyl protons are all shifted upfield, and it appears the order of chemical shift changes from ortho $<$ para $<$ meta to para $<$ ortho $<$ meta (see Table 2). It also shows the downfield $\mathrm{O} t$-Bu peak (1.1 ppm), but the integration of this peak (Figure $3)$ is far lower than the expected anion, $\mathrm{K}\left[\left(\mathrm{C}_{6} \mathrm{H}_{5} \mathrm{CH}_{2}\right)_{4} \mathrm{Zr}\left(\mathrm{O} t-\mathrm{C}\left(\mathrm{CH}_{3}\right)_{3}\right]\right.$. Further reactivity of this solid, including multiple alkylation of organic compounds, remains to be explored. 
Table 2. ' $\mathrm{H} N M R$ data for $\mathrm{O}-\mathrm{C}\left(\mathrm{CH}_{3}\right)_{3}$ and $\mathrm{ZT}-\mathrm{CH}_{2} \mathrm{C}_{6} \mathrm{H}_{5}$ complexes in THF-dg.

\begin{tabular}{cccccc}
\hline & & \multicolumn{4}{c}{$\mathrm{C}_{6} \mathrm{H}_{5}$} \\
\cline { 5 - 6 } Compound & $0-\mathrm{C}\left(\mathrm{CH}_{3}\right)_{3}$ & $\mathrm{CH}_{2}$ & & ortho(d) & para(t) meta(t) \\
\hline $\mathrm{KO}-\mathrm{C}\left(\mathrm{CH}_{3}\right)_{3}$ & 0.98 & & & & \\
$\mathrm{Zr}\left(\mathrm{CH}_{2} \mathrm{C}_{6} \mathrm{H}_{5}\right)_{4}$ & & 2.20 & 6.7 & 6.9 & 7.2 \\
$\mathrm{Zr}\left(\mathrm{CH}_{2} \mathrm{C}_{6} \mathrm{H}_{5}\right)_{4}+\mathrm{KO}-\mathrm{C}\left(\mathrm{CH}_{3}\right)_{3}$ & 1.1 & 2.10 & 6.6 & 6.5 & 6.9 \\
\hline
\end{tabular}

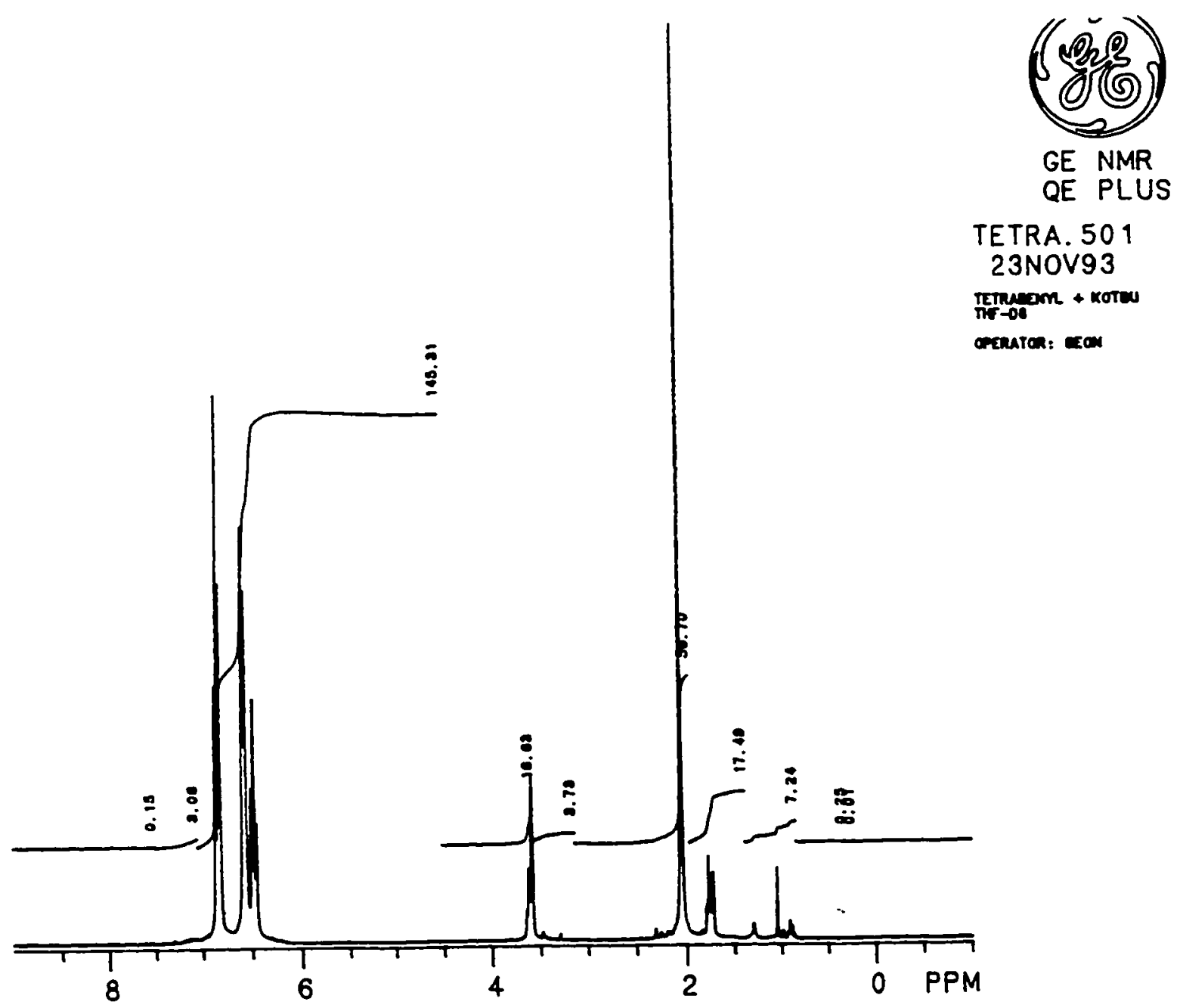

Figure 3. ${ }^{1} \mathrm{H} N M R$ spectrum of product from $\mathrm{KOt}-\mathrm{Bu}+\mathrm{Zr}\left(\mathrm{CH}_{2} \mathrm{C}_{6} \mathrm{H}_{5}\right)_{4}$ in THF-d8 solution. The small upfield peaks around $1.0 \mathrm{ppm}$ are $\mathrm{O}-\mathrm{C}\left(\mathrm{CH}_{3}\right)_{3}$. 


\section{Experimental}

A. General Procedures. All operations were carried out under high-purity nitrogen using standard Schlenk techniques or in an inert atmosphere-filled $\left(N_{2}\right.$ or $\left.A r\right)$ glove box. Solvents were dried and degassed as described below. ${ }^{1} \mathrm{H}$ and ${ }^{13} \mathrm{C}$ NMR spectra were obtained on a GE QE Plus $300 \mathrm{MHz}$ Spectrometer. Proton and carbon shifts were calibrated using the deutrated solvent standard.

B. Materials. Tetrahyrofuran (THF), hexane, ether and pentane were distilled under nitrogen from sodium benzophenone ketyl and vacuum transferred to storage flasks sealed with Teflon screw valves. Dimethylzirconocene, ${ }^{9,}$ diphenylzirconocene, ${ }^{10}$ dibenzylzirconocene, ${ }^{11}$ and tetrabenzylzirconium ${ }^{12}$ were prepared according to published procedures. $\mathrm{ZrCh}_{4}$ and $\mathrm{PhLi}$ were purchased from Fluka and Aldrich, respectively. Potassium tert-butoxide was purchased from Aldrich and sublimed prior to use. THF- $d_{8}$ was purified by vacuum distillation from Na/benzophenone ketyl directly into the NMR tube. Benzene- $d_{6}$ and acetonitrile- $d_{3}$ were distilled from $\mathrm{Na} / \mathrm{benzophenone} \mathrm{ketyl} \mathrm{and}$ $\mathrm{CaH}_{2}$, respectively, and vacuum transferred to a screw top bottle to be stored in a Glovebox (the acetonitrile- $d_{3}$ was deoxygenated using three freeze-pump-thaw cycles). High purity $(99.999 \%) \mathrm{N}_{2}$ was purchased from Air Products. All other reagents were purchased from standard vendors as reagent or higher grades and used without further purification. 


\section{NMR tube reactions in THF- $d_{\ell}$.}

1. $\mathrm{Cp}_{2} \mathrm{ZrPh}_{2}$ with $4 \mathrm{KO}-\mathrm{Bu}$. Diphenylzirconocene (38 $\left.\mathrm{mg}, 0.10 \mathrm{mmol}\right)$ and potassium tert-butoxide ( $45 \mathrm{mg}, 0.40 \mathrm{mmol}$ ) were added to a NMR tube. The tube was fitted to a vacuum line and the THF- $d_{8}$ was vacuum distilled into it at $-198{ }^{\circ} \mathrm{C}$. After the tube was sealed with a torch under vacuum, it was removed from liquid nitrogen and the frozen solution was allowed to slowly warm to room temperature. During this time, a reaction occurred, resulting in a purple solution and white solid. As the reaction progresses the reaction mixture became green in color. After $75 \mathrm{~min}$., a yellow solution was formed and white precipitate was observed: ' $\mathrm{H}$ NMR (300 MHz) $\delta 0.99(\mathrm{~s}), 1.23(\mathrm{~s})$, $1.73(\mathrm{~s}), 3.58(\mathrm{~s}), 5.63(\mathrm{~s}), 7.29(\mathrm{~m}) .{ }^{13} \mathrm{C} \mathrm{NMR}(300 \mathrm{MHz}) \delta 35.0,37.5,105.2,128.8$, 129.1.

2. $\mathrm{Cp}_{2} \mathrm{Zr}\left(\mathrm{CH}_{2} \mathrm{Ph}\right)_{2}$ with $4 \mathrm{KO}$-Bu. Reaction 2 was performed in the same manner as described for reaction 1 above. Among the products, toluene and $\mathrm{KCp}$ were identified by comparison of their NMR with authentic samples. Other spectral characteristics were too complex to be interpreted.

\section{Reaction of $\mathrm{Zr}\left(\mathrm{CH}_{2} \mathrm{Ph}\right)_{4}$ with $\mathrm{KOt}-\mathrm{Bu}$. In a $100 \mathrm{~mL}$ Schlenk tube, tetrabenzyl} zirconium $(1.0 \mathrm{~g}, 2.2 \mathrm{mmol})$ in toluene $(30 \mathrm{~mL})$ was added to $\mathrm{KO} t-\mathrm{Bu}(0.25 \mathrm{~g}, 2.2 \mathrm{mmol})$ in THF $(10 \mathrm{~mL})$ while stirring at $-50^{\circ} \mathrm{C}$. The mixture was stirred until an orange solution was obtained from the original yellow solution. After $1.5 \mathrm{hr}$. $\left(1 \mathrm{hr}\right.$. at $\left.-30^{\circ} \mathrm{C}\right)$ the solution 
was concentrated to $10 \mathrm{~mL}$ at room temperature. Hexane $(20 \mathrm{~mL})$ was added via cannula until the solution was clear and an orange precipitate began to form. The solution was allowed to stand for an additional $10 \mathrm{~min}$. at room temperature to let the fine orange solid settle before the mother liquor was removed via cannula. The solid was washed twice with hexane ( $10 \mathrm{~mL}$ each at room temperature), dried in vacuo, and weighed in the glove box $\left(1.5 \mathrm{~g}, 125 \%\right.$ yield based on the formulation $\mathrm{K}\left[\left(\mathrm{C}_{6} \mathrm{H}_{5} \mathrm{CH}_{2}\right)_{4} \mathrm{ZrO}-\mathrm{C}\left(\mathrm{CH}_{3}\right)_{3}\right]$. ${ }^{1} \mathrm{H}$ NMR $\left(\mathrm{THF}-\mathrm{d}_{8}\right) \delta 2.10(\mathrm{~s}, 2 \mathrm{H}), 6.5(\mathrm{t}, \mathrm{lH}), 6.6(\mathrm{~d}, 2 \mathrm{H}), 6.9(\mathrm{t}, 2 \mathrm{H})$, and some smail peaks. ${ }^{1} \mathrm{H}$ NMR spectral characteristics are also found in Table 2 and Figure 3.

The solid spontaneously inflamed on contact with air. It was light-sensitive because the color of the solid changed from orange to dark gray-yellow after several hours in the glove box. When the solid was redissolved in THF- $d_{s}$ in the NMR tube, it was a black solution.

\section{E. Synthesis.}

1. $\mathrm{K}\left[(t-\mathrm{BuO})_{3} \mathrm{Zr}\left(\mathrm{CH}_{3}\right)_{2}\right]$. To a flame-dried $200 \mathrm{~mL}$ Schlenk flask equipped with a stir bar was added $2.01 \mathrm{~g}(8.00 \mathrm{mmol})$ of $\mathrm{Cp}_{2} \mathrm{Zr}\left(\mathrm{CH}_{3}\right)$ and $\mathrm{KO} t-\mathrm{Bu}(2.69 \mathrm{~g}, 24.0 \mathrm{mmol})$ in the glove box. The flask was then cooled to below $-60^{\circ} \mathrm{C}$ in a dry ice/acetone bath. Tetrahydrofuran $\left(40 \mathrm{~mL},-50^{\circ} \mathrm{C}\right)$ was slowly added via cannula. The resulting white suspension was stirred for $30 \mathrm{~min}$. at $-30^{\circ} \mathrm{C}$, during which time the white suspension slowly changed, first to a colorless solution and then a white solid (KCp) precipitated. 
The solvent was concentrated to $20 \mathrm{~mL}$ at $-20^{\circ} \mathrm{C}$. After adding cold hexane $(20 \mathrm{~mL})$, the solution was cooled to $-78^{\circ} \mathrm{C}$ for $1 \mathrm{hr}$ and the colorless supernatant liquid was transferred via cannula to a flame-dried $100 \mathrm{~mL}$ Schlenk flask at $-78^{\circ} \mathrm{C}$. The solution was concentrated to $20 \mathrm{~mL}$ at $-20^{\circ} \mathrm{C}$ and more cold hexane (20 mL) was added. After cooling (overnight $/-50^{\circ} \mathrm{C}$ ), $\mathrm{KCp}$ was removed as a white crystalline solid. The cannulatransferred solution was concentrated to $5 \mathrm{~mL}$ and cold hexane $(10 \mathrm{~mL})$ was added, at which point a fine white solid formed. The supernatant was removed via cannula and the solid washed twice with hexane ( $10 \mathrm{~mL}$ each) at room temperature, and then dried in vacuo for 2 hours. The product, a fine white powder, weighed $1.1 \mathrm{~g}$ ( $36 \%$ yield). Attempts at recrystallization failed. The NMR analysis revealed trace impurities. ${ }^{1} \mathrm{H}$ NMR (THF- $\left.d_{8}\right) \delta 1.29(\mathrm{~s}, 27 \mathrm{H}),-0.57(\mathrm{~s}, 6 \mathrm{H}) ;{ }^{13} \mathrm{C}$ NMR (THF- $\left.d_{8}\right) \delta 72.5$ and $33.6(\mathrm{OC}-$ $\left.\left(\mathrm{CH}_{3}\right)_{3}\right), 24.5\left(\mathrm{CH}_{3}\right)$. Unknown peaks: ${ }^{1} \mathrm{H}$ NMR (THF- $\left.d_{8}\right) \delta 1.27$ (s); ${ }^{13} \mathrm{C}$ NMR (THF- $\left.d_{8}\right)$ 72.2 and $33.8\left(\mathrm{OC}-\left(\mathrm{CH}_{3}\right)_{3}\right.$ ?), $30.8\left(\mathrm{CH}_{2}\right.$ ?). ${ }^{1} \mathrm{H}$ NMR and ${ }^{13} \mathrm{C}$ NMR spectral data are found in Table 1, Figure 1 and Figure 2.

Anal. calcd. for $\mathrm{C}_{14} \mathrm{H}_{33} \mathrm{O}_{3} \mathrm{ZrK}: \mathrm{C}, 44.28 ; \mathrm{H}, 8.76$. Found: $\mathrm{C}, 42.04 ; \mathrm{H}, 8.60$.

2. $\mathrm{Cp}_{2} \mathrm{ZrPh}_{2}$. The synthesis of the title compound was similar to Samuel's procedure. ${ }^{10}$ To a $250 \mathrm{~mL}$ Schlenk flask equipped with a stir bar was added $5.00 \mathrm{~g}(15.8$ $\mathrm{mmol})$ of $\mathrm{ZrCl}$. Diethyl ether $(100 \mathrm{~mL})$ was added via cannula into the flask with stirring, producing a white suspension. The flask was cooled $-40^{\circ} \mathrm{C}$ (dry ice-acetone bath) and 
phenyllithium ( $20 \mathrm{~mL}$ of $1.8 \mathrm{M}$ in ether, $36 \mathrm{mmol}$ ) was added via syringe to a dropping funnel $(250 \mathrm{~mL})$ to which was also added $15 \mathrm{~mL}$ of ether. The phenyllithium solution was added slowly over a $45 \mathrm{~min}$, after which stirring was continued at same temperature $(-40$ ${ }^{\circ} \mathrm{C}$ ) for $1 \mathrm{hr}$. White solid was generated from the beginning of the addition. The temperature was allowed to rise gradually to $0{ }^{\circ} \mathrm{C}$, and then the dry ice-acetone bath was replaced with an ice bath. On the ice bath $\left(0.5^{\circ} \mathrm{C}\right)$ the solvent was evaporated under reduced pressure and the resulting white solid on the glass wall was scraped under nitrogen purge to let the powder settle on the bottom of the flask. Using a filtered cannula, the solid residue was washed with two $20 \mathrm{~mL}$ portions of pentane. The solid was then extracted with three $15 \mathrm{~mL}$ portions. The extract was concentrated to $25 \mathrm{~mL}$., and then placed in a freezer $\left(-50^{\circ} \mathrm{C}\right.$, overnight $)$ to produce a white crystalline solid. The solid was washed twice with pentane, dried in vacuo, and weighed in the glove box $(0.92 \mathrm{~g}$; $16 \%) .{ }^{1} \mathrm{H} N M R\left(\mathrm{C}_{6} \mathrm{D}_{6}\right) \delta 5.71(\mathrm{~s}, 10 \mathrm{H}), 7.1-7.4(\mathrm{~m}, 12 \mathrm{H}) ;{ }^{13} \mathrm{C} \mathrm{NMR}\left(\mathrm{C}_{6} \mathrm{D}_{6}\right.$, Figure 4) $\delta$ $112.2(\mathrm{Cp}), 125,126,135,183(\mathrm{Ph})$. To increase the yield ( $80 \%$ in reference), new PhLi reagent was required.

The side-product indicated by NMR analysis (Figure 5) was isolated as a white crystalline solid from $\mathrm{Et}_{2} \mathrm{O} /$ toluene (recrystallized three times) and identified as the dimer product, $\left[\mathrm{C}_{2} \mathrm{Zr}(\mathrm{Ph})\right]_{2} \mathrm{O},{ }^{13}$ which was confirmed by the hydrolysis of $\mathrm{Cp}_{2} \mathrm{Zr}_{\mathrm{r} h}$ in an 


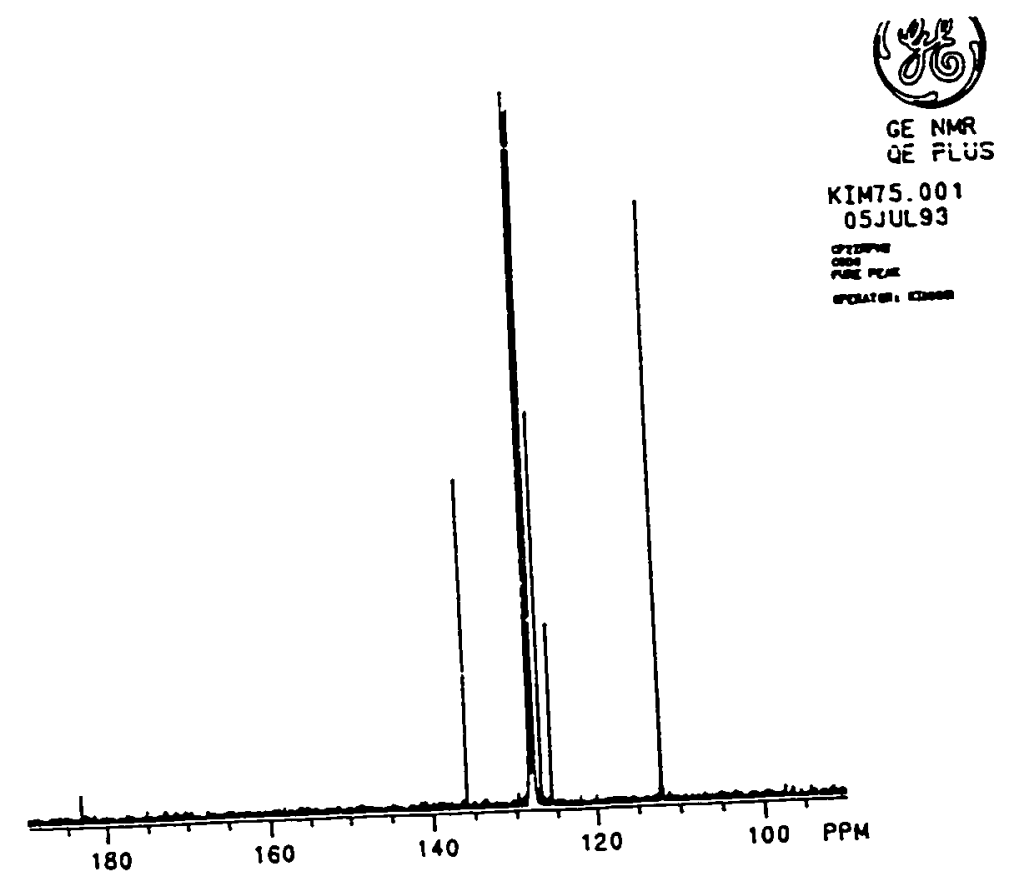

Figure 4. ${ }^{13} \mathrm{C} N M R$ spectrum of $\mathrm{Cp}_{2} \mathrm{ZrPh}_{2}$ in $\mathrm{C}_{6} \mathrm{D}_{6}$.

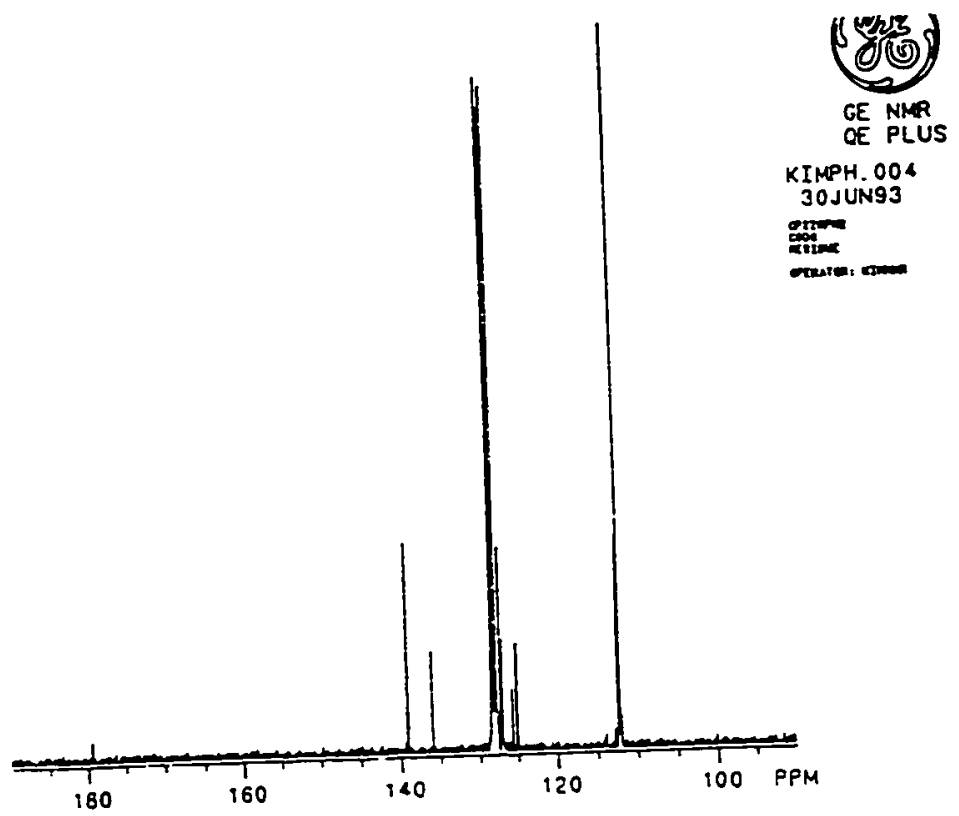

Figure $5 .{ }^{13} \mathrm{C} N M R$ spectrum of the mixture of $\mathrm{Cp}_{2} \mathrm{Zr} \mathrm{Ph}_{2}$ and $\left[\mathrm{Cp}_{2} \mathrm{ZrPh}\right]_{2} \mathrm{O}$ in $\mathrm{C}_{6} \mathrm{D}_{6}$. 
NMR tube and by melting point $\left(262{ }^{\circ} \mathrm{C}\right) .{ }^{1} \mathrm{H} N M R\left(\mathrm{C}_{6} \mathrm{D}_{6}\right) \delta 5.71(\mathrm{~s}, 20 \mathrm{H}), 7.1-7.4(\mathrm{~m}$,

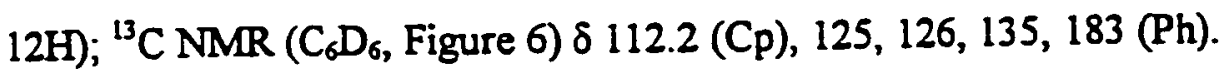

Solubility Studies.

In order to isolate title compound, we have studied the solubilities of reaction mixtures: (1) Solubility in $\mathrm{Et}_{2} \mathrm{O}, \mathrm{Cp}_{2} \mathrm{ZrPh}_{2}>\left[\mathrm{Cp}_{2} \mathrm{ZrPh}\right]_{2} \mathrm{O}>\mathrm{Cp}_{2} \mathrm{ZrCl}_{2}>\mathrm{LiCl}$ Solubility in toluene, $\mathrm{Cp}_{2} \mathrm{ZrPh}_{2} \sim\left[\mathrm{Cp}_{2} \mathrm{ZrPh}\right]_{2} \mathrm{O}>\mathrm{Cp}_{2} \mathrm{ZrCl}_{2}>\mathrm{LiCl}$ (3) Solubility of $\mathrm{Cp}_{2} \mathrm{ZrPh}_{2}$ in pentane is $1 \mathrm{mg} / \mathrm{mL}$ at room temperature.

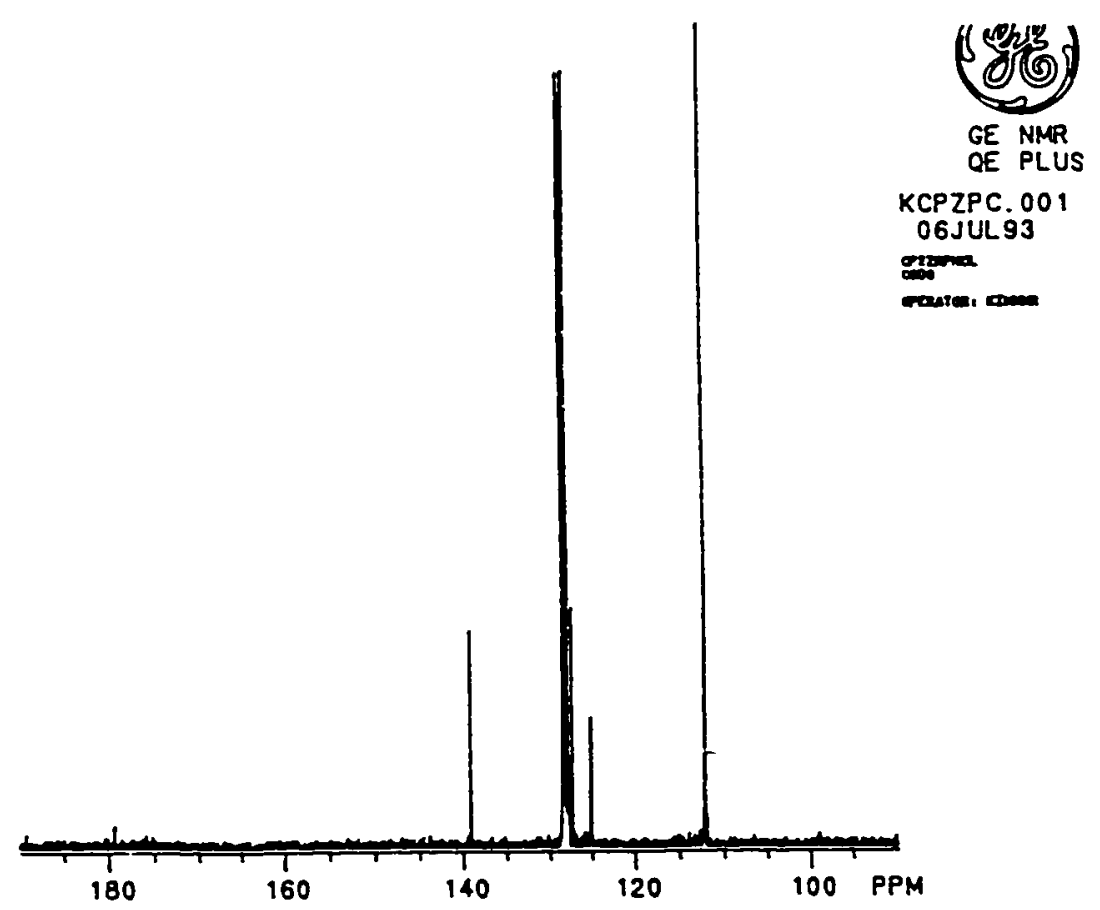

Figure 6. ${ }^{13} \mathrm{C} N M R$ spectrum of $\left[\mathrm{C}_{\mathrm{p}_{2}} \mathrm{ZrPh}\right]_{2} \mathrm{O}$ in $\mathrm{C}_{6} \mathrm{D}_{6}$. 
3. $\mathrm{Cp}_{2} \mathrm{Zr}\left(\mathrm{CH}_{3}\right)_{2}$. The synthesis of the title compound was similar to Samuel's procedure. ${ }^{9} A$ white suspension of $\mathrm{Cp}_{2} \mathrm{ZrCl}_{2}\left(35.0 \mathrm{~g}, 0.119\right.$ mole) in $150 \mathrm{~mL} \mathrm{Et} t_{2} \mathrm{O}$ was stirred at $0{ }^{\circ} \mathrm{C}$. With stirring at $0{ }^{\circ} \mathrm{C}$, the $135.6 \mathrm{~mL}$ of $\mathrm{CH}_{3} \mathrm{Li} / \mathrm{Et}_{2} \mathrm{O}(1.77 \mathrm{M}, 0.238 \mathrm{~mol})^{14}$ was added via cannula over a period of $40 \mathrm{~min}$. The mixture was allowed to warm, stirred at room temperature for 2 hours, and filtered via cannula. The residue was extracted with $50 \mathrm{~mL}$ of ether. The combined supernatant was dried in vacuo. Two sublimations at 120

${ }^{\circ} \mathrm{C}$ for 3 hours were conducted to obtain a crystalline pale yellow solid $(22.2 \mathrm{~g}, 74 \%) .{ }^{1} \mathrm{H}$

NMR (THF- $\left.d_{8}\right) \delta 6.08(\mathrm{~s}, 10 \mathrm{H}),-0.42(\mathrm{~s}, 6 \mathrm{H}) ;{ }^{13} \mathrm{C}$ NMR (THF- $\left.d_{8}\right) \delta 111.1(\mathrm{Cp}), 26.9$ $\left(\mathrm{CH}_{3}\right)$.

\section{References}

1. (a) Straus, D. A. Ph.D. Dissertation, California Institute of Technology, 1983. (b) Straus, D. A.; Grubbs, R. H. J. Amer. Chem. Soc. 1982, 104, 5499. (c) Ho. S. C. H.; Straus, D. A.; Armantrout, J.; Schaefer, W. P.; Grubbs, R. H. J. Amer. Chem. Soc. 1984, 106, 2210.

2. (a) Askham, F. R.; Carroll, K. M.; Alexander, S. J.; Rheingold, A. L.; Haggerty, B. S. Organometallics 1993, 12, 4810. (b) Askham, F. R.; Carroll, K. M.; Briggs, P. M.; Rheingold, A. L.; Haggerty, B. S. Organometallics 1994, 13, 2139.

3. Fermin, M. C.; Stephan, D. W. J. Amer. Chem. Soc. 1995, 117, 12645.

4. Takagi, K.; Rousset, C. J.; Negishi, E-I. J. Amer. Chem. Soc. 1991, 113, 1440.

5. (a) Reetz, M. T.; Westermann, J.; Steinbach, R.; Wenderoth, B.; Peter, R; Ostarek, R.; Maus, S. Chem. Ber. 1985, 118, 1421. (b) Reetz, M. T.; Steinbach, R.; Westermann, J. Peter, R.; Wenderoth, B. Chem. Ber. 1985, 118, 1441. (c) Reetz, M. T. In Topics in Current Chemistry; Boschke, F. L., Ed.; Springer: Berlin, 1982; Vol. 106, pp 1-54. (d) Seebach, D.; Weidmann, B.; Wilder, L. In Modern Synthetic Methods; Scheffold, R., Ed.; Salle: Frankfurt/Sauerlander: Aarau, 1983; Vol. 3, p 217.

6. Towne, R. W. MS Thesis, San Jose State University, 1994, Chapter 2. 
7. Prinz, H; Bott, S. G.; Atwood, J. L. J. Amer. Chem. Soc. 1986, 108, 2113.

8. Erker, G.; Kropp, K. J. Amer. Chem. Soc. 1979, 101, 3659.

9. (a) Samuel, E.; Maillard, P.; Giannotti, C. J. Organomet. Chem. 1977, 1+2, 289. (b) Wailes, P. C.; Weigold, H.; Bell, A. P. J. Organomet. Chem. 1972, 34, 155.

10. Samuel, E.; Rausch, M. D. J. Amer. Chem. Soc. 1973, 95, 6263.

11. (a) Fachinetti, G.; Floriani, C. J. Chem. Soc., Chem. Commun. 1972, 654. (b) Manriquez, M; McAlister, D. R.; Sanner, R. D.; Bercaw, J. E. J. Amer. Chem. Soc. 1978, 100, 2716.

12. Zucchini, U.; Albizzati, E.; Giannini, U. J. Organomet. Chem. 1971, 26, 357.

13. (a) Wailes, P. C.; Coutts, R. S. P.; Weigold, H. Organometallic Chemistry of Titanium, Zirconium, and Halfnium Academic Press: New York, 1974; p 125. (b) The dimer is formed via a following equation:

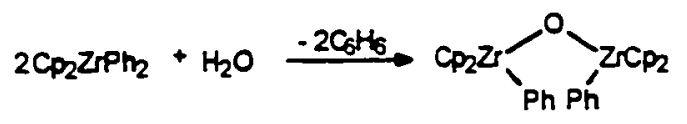

14. $\mathrm{CH}_{3} \mathrm{Li}$ is prepared from $\mathrm{CH}_{3} \mathrm{I}$ and lithium metal (Organic Syntheses, Collective Vol. V, p 860). 


\title{
Chapter III.
}

\section{Reactivity of $\mathrm{K}\left[(\mathrm{O} t-\mathrm{Bu})_{3} \mathrm{Zr}\left(\mathrm{CH}_{3}\right)_{2}\right]$ (1) with Carbonyl Substrates.}

\section{Introduction}

\begin{abstract}
Although Reetz ${ }^{1}$ and Seebach ${ }^{2}$ have studied the in situ generated titanium "ate" complexes, the anion $\mathrm{K}\left[(t-\mathrm{BuO})_{3} \mathrm{Zr}\left(\mathrm{CH}_{3}\right)_{2}\right](1)$ we have prepared has not been reported previously. Previously in our laboratories, ${ }^{3}$ we characterized the alkylation of carbonyl compounds by $\mathrm{Cp}_{2} \mathrm{Zr}\left(\mathrm{CH}_{3}\right)_{2}$ in the presence of excess $\mathrm{KO} t-\mathrm{Bu}$ (Scheme 8 in Chapter I) and proposed such a zirconium "ate" complex as an active intermediate. Although our postulated in situ generated "ate" intermediate methylated non-enolizable aldehydes and ketones, there was no methylation observed for enolizable ketones. We also previously compared the selectivity from the equimolar mixture of benzaldehyde and benzophenone with various reaction conditions for the in situ generated "ate" intermediate and for the "Seebach reagent" [which was prepared in situ by combining methyllithum with $\left.\mathrm{ClZr}(\mathrm{OBu})_{3}\right]$. In Chapter II, we described the isolation of 1 as a white powder which was thermally stable under inert gas atmosphere. In this Chapter, we present detailed alkylation reactivity of $\mathbf{1}$ and compare it with the neutral and presumably anionic Seebach and Reetz reagents as well as our $\mathrm{Cp}_{2} \mathrm{Zr}\left(\mathrm{CH}_{3}\right)_{2} / \mathrm{KO}$ - $\mathrm{Bu}$ reagent system. The selectivity in the presence of ketones and aldehydes and diasteroselectivity have been studied.
\end{abstract}




\section{Results and Discussion}

\section{A. Reactivity of 1 .}

The reactivity of complex 1 was examined by its reactions with a variety of aldehydes and ketones under the same conditions of our previous $\mathrm{Cp}_{2} \mathrm{Zr}\left(\mathrm{CH}_{3}\right)_{2} / \mathrm{KO} t-\mathrm{Bu}$ reagent system studies. The methylation reactions were performed under inert atmosphere in $\mathrm{THF}$ at $0^{\circ} \mathrm{C}$ for $30 \mathrm{~min}$. (Table 1). Two equivalents of aldehydes (or ketones) were used, assuming two methyl groups transfer, and the reaction was followed by hydrolysis with aqueous $\mathrm{KF}$ and standard benchtop work up. The yields were quantitated using $\mathrm{GC}$ analysis with biphenyl as an internal standard.

1. Yields. A series of carbonyl compounds (Table 1) has been alkylated using the complex 1 . Aldehydes and ketones react smoothly and the yields were quantitated using GC analysis with an internal standard. Generally, a 1:2 mixture of 1 and carbonyl substrates was used in THF at $0{ }^{\circ} \mathrm{C}$. Based on the yields (around 50 and $60 \%$ for sterically hindered aldehydes and enolizable ketones), it appeared that the first methylation was easier than the second methyl group transfer. This may indicate that a generated ( $t$ $\mathrm{BuO})_{3} \mathrm{Zr}(\mathrm{OR}) \mathrm{CH}_{3}^{-}$(OR was a methylated aldehyde or ketone) intermediate may be less reactive than the parent "ate" complex. 
Table 1. Methylation with 1 in $\mathrm{THF}$ at $0^{\circ} \mathrm{C}$ for $30 \mathrm{~min}$.

Starting Compound

a: In the reaction of two equivalents of aldehyde (or ketone) with complex 1, yields were based on [aldehyde] (or [ketone]), assuming two methyl groups transfer. Notebook page number was in each parenthesis.

b: 10[benzophenone]:1[complex 1] reaction for $60 \mathrm{~min}$.; assuming two methyl groups transfer.

c: 1:1 reaction; yield based on [cyclohexanone]. 
2. Reaction products from benzaldehyde. The methylation of benzaldehyde with complex $\mathbf{1}$ gave acetophenone ( $\mathbf{A}$ in Figure 1$)$ and benzyl alcohol ( $\mathbf{C}$ in Figure 1) as side products in the gas chromatographic analysis (Figure 1). Graphs in Figure 1 were drawings, for simplicity, of original $G C$ graphs. When this reaction was performed at room temperature, the benzyl alcohol and acetophenone were obtained in higher yields.<smiles>O=Cc1ccccc1</smiles><smiles>CC(C)CCCCCC(C)(C)C</smiles><smiles>CC(=O)c1ccccc1I</smiles><smiles>CC(O)c1ccccc1</smiles>

(4.43)<smiles>OCC1=CCCCC1</smiles>

(3.79)

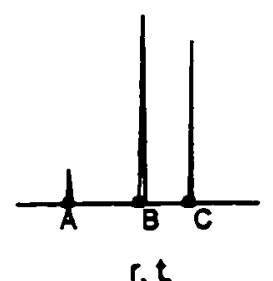

o oc

r. $t$

Figure 1. Methylation of aldehyde with complex 1 in THF for $30 \mathrm{~min}$. Figures in brackets represent $\mathrm{GC}$ retention time (min.). At $0^{\circ} \mathrm{C}, \mathrm{A}$ and $\mathrm{B}$ were both below $2 \%(98 \%$ C) $\mathrm{GC}$ yields (relative). At room temperature, the ratio (relative $\mathrm{GC}$ yield) was $2 \%: 54 \%: 44 \%$ (A:B:C).

Scheme 1.

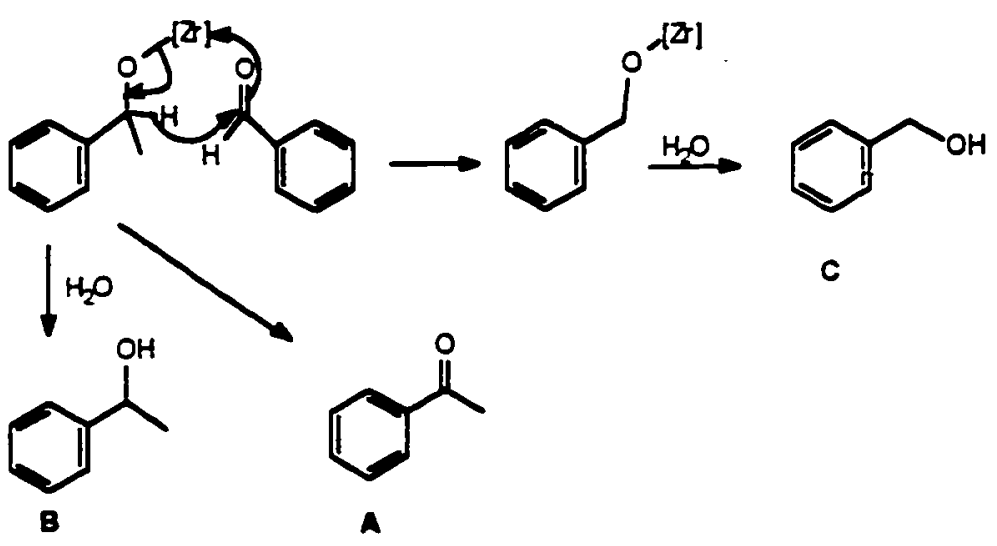


As shown in Scheme 1, a Meerwein-Ponndorf-Verley reduction ${ }^{4}$ type (a cyclic transition state) may be involved for the side products.

3. Reactions with acetophenone and cycloheranone. It should be noted that, aithough the in situ generated zirconium "ate" complex (Scheme 8 in Chapter l) was not able to methylate enolizable ketones such as acetophenone and cyclohexanone, complex 1 gave clean methylation in high yield (see Table 1) at $0{ }^{\circ} \mathrm{C}$. Cyclohexanone gave $95 \%$ yield based upon one methyl group transfer. However, in the methylation of acetophenone in the ratio of 5:1 (1:acetophenone), there still remained unreacted acetophenone (Table 2). Therefore, it appeared there may be a side reaction involving a zirconium O-bound enolate complex as an intermediate formed by removing methane gas ( Scheme 2). Such an enolate complex would give acetophenone upon hydrolysis. Deuterium labeling studies have not yet been performed, in which quenching with $\mathrm{D}_{2} \mathrm{O}$ would give deuterated acetophenone.

Table 2. Methylation of acetophenone in THF at $0^{\circ} \mathrm{C}$ for $30 \mathrm{~min}$.

\begin{tabular}{ccc}
\hline Ratio $^{a}$ & GC Yield (\%) & Note \\
\hline $2: 1$ & 56 & SJK-II-14 \\
$1: 5$ & 75 & SJK-II-34 \\
\hline
\end{tabular}

a: The ratio was [acetophenone]:[complex 1]

b: Yields based on two methyl groups transfer. 


\section{Scheme 2.}

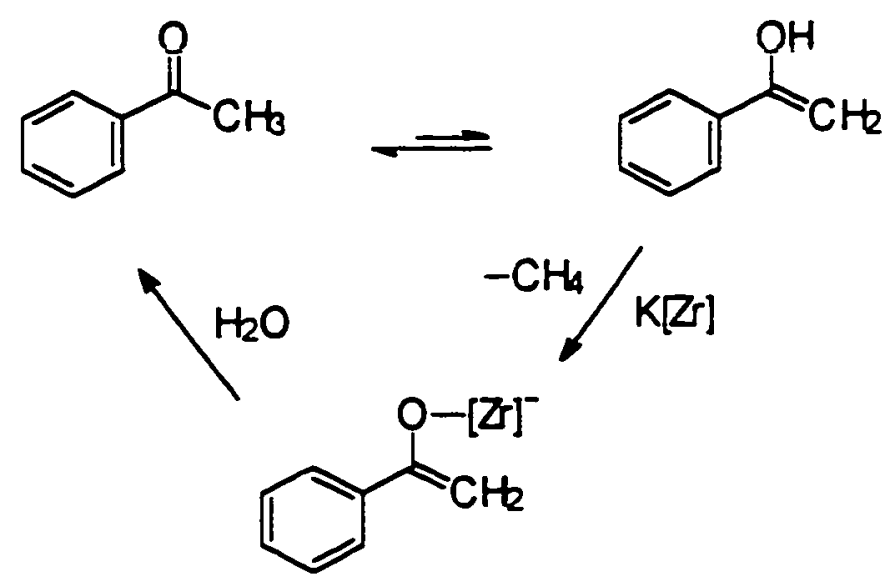

\section{B. Selectivity.}

1. Benzaldehyde vs. other aldehydes. The competition reaction of benzaldehyde and $o$-tolualdehyde (slightly more sterically hindered) gave no significant selectivity; however, the reaction comparing mesitaldehyde $v s$. benzaldehyde showed mild selectivity to benzaldehyde (Scheme 3). On the other hand, in the competition reaction of benzaldehyde $v$ s.o-tolualdehyde, ${ }^{3 b}$ the in situ generated complex 1 and "Seebach reagent", prepared in situ by the reaction of $(n-\mathrm{BuO})_{3} \mathrm{ZrCl}$ and $\mathrm{LiCH}_{3}$, gave lower yieids; however, the poor selectivity was similar to complex 1 .

The reaction of in situ generated complex 1 with a mesitaldehyde and benzaldehyde mixture gave low yield ( $11 \%$ ) at one minute, and the product disappeared with time perhaps due to a Meerwein-Ponndorf-Verley reduction (see Scheme 1) 
process. ${ }^{3 b}$ In the "Seebach reaction" condition, ${ }^{3 b}$ the selectivity to benzaldehyde was slightly little higher than that of complex 1 (see Scheme 3).

Scheme 3.<smiles>O=Cc1ccccc1</smiles><smiles>CC(=O)c1ccccc1C</smiles><smiles>[CH]C</smiles>

2:2:1 reaction, $\mathrm{THF} / 0^{\circ} \mathrm{C} / 30 \mathrm{~min}$. *

$\mathrm{Cp}_{2} \mathrm{Zr}\left(\mathrm{CH}_{3}\right)_{2} / 4 \mathrm{KO}-\mathrm{Bu}, \mathrm{THF} / 0^{\circ} \mathrm{C} / 60 \mathrm{~min}$ $(n-\mathrm{BuO})_{3} \mathrm{ZrCH}_{3}, \mathrm{THF} /-50^{\circ} \mathrm{C} / 60 \mathrm{~min}$.<smiles>Cc1ccccc1C(C)O</smiles>

$1: 1.08$ (SJK-II-30) $(84 \%$ total yield) $1.08: 1$ (RWT-II-110) (35\% total yield) $1.27: \quad 1$ (RWT-III-133) (58\% total yield)<smiles>O=Cc1ccccc1</smiles><smiles>Cc1cc(C)c(C=O)c(C)c1</smiles><smiles>[CH2-]C</smiles><smiles>Cc1cc(C)c(C(C)O)c(C)c1</smiles>

2:2:1 reaction, $\mathrm{THF} / 0^{\circ} \mathrm{C} / 30 \mathrm{~min}$. $(n-\mathrm{BuO})_{3} \mathrm{ZrCH}_{3}, \mathrm{THF} / 0^{\circ} \mathrm{C} / 60 \mathrm{~min}$. $2.84: 1$ (SJK-I-148) (77\% total yield) $3.51: 1$ (RWT-III-10) (131\% total yield) Competition reactions of 1 with benzaldehyde and various aldehydes. * 2:2:1 reaction was 2[benzaldehyde]:2[competing aldehyde]:1[complex 1 ] Yields were calculated by an internal standard method using biphenyl.

2. Benzaldehyde vs. ketones. Selectivities of complex $\mathbf{l}$ in reactions with equimolar mixtures of benzaldehyde and ketones (benzophenone, acetophenone, and 
cyclohexanone) were listed in Table 3. Complex 1 distinguishes perfectly between aldehyde and ketones with high $G C$ yields which were calculated based on transfer of two methyl groups.

Table 3. Competition reactions of 1 with benzaldehyde and various ketones in THF at $0^{\circ} \mathrm{C}$ for $30 \mathrm{~min}^{2}$

\begin{tabular}{cccl}
\hline Ketone & ${\text { Ratio of } \text { Reagent }^{\mathrm{b}}}^{\mathrm{C}}$ & Yield $(\%)^{\mathrm{N}}$ & Note \\
\hline Benzophenone & $10: 10: 1$ & $80^{\mathrm{c}}$ & SJK-II-21 \\
Acetopheonone & $10: 10: 1$ & 76 & SJK-II-32 \\
Cyclohexanone & $2: 2: 1$ & 77 & SJK-I-142 \\
& & $78^{\mathrm{c}}$ & SJK-II-10 \\
\hline
\end{tabular}

a: The only product was $\alpha$-methylbenzyl alcohol by $G C$ analysis.

b: The ratio was [aldehyde]:[ketone]:[complex 1].

c: The yield from $60 \mathrm{~min}$. reaction.

It was significant that complex 1 gave the $>99 \%$ aldehyde-selectivity with $76 \%$ of conversion yield within $30 \mathrm{~min}$. at $0^{\circ} \mathrm{C}$ in the $1: 1$ mixtures of benzaldehyde and acetophenone competition (Tables 3 and 4). In an early report by Reetz, ${ }^{1}$ similar selectivity (>98\% to aldehyde, see Table 4) was also observed with the methyltitanium triisopropoxide reagent in the same competition, although its reaction was slower than our complex 1 . The in situ generated zirconium reagent $\left(\mathrm{CH}_{3} \mathrm{Zr}(\mathrm{OBu})_{3}\right)$ was even slower than titanium reagent $\left(\mathrm{CH}_{3} \mathrm{Ti}(\mathrm{O} i-\mathrm{Pr})_{3}\right)$ and the selectivity $(95 \%$ to aldehyde) and yield (incomplete reaction after $15 \mathrm{hr}$ at room temperature) were not as good as those of the titanium reagent. ${ }^{2}$ On the other hand, the methyllithium gave the $50: 50\left(\mathrm{PhCH}(\mathrm{OH}) \mathrm{CH}_{3}\right.$ : $\left.\mathrm{PhC}(\mathrm{OH})\left(\mathrm{CH}_{3}\right)_{2}\right)$ mixtures and benzylalcohol from a Meerwein-Ponndorf-Verley 
reduction, as well as it gave further complicated aldol reactions between the carbonyl compounds. ${ }^{16,2}$

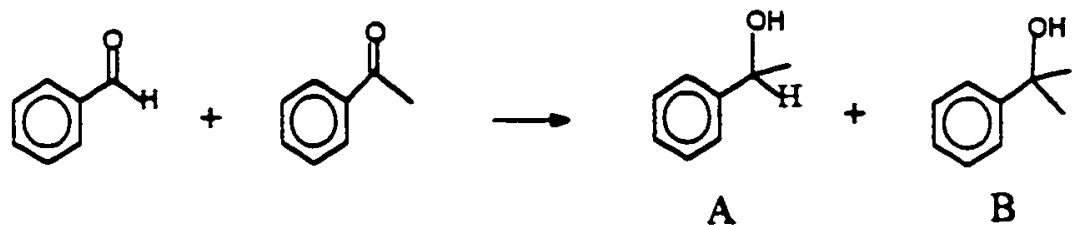

Table 4. Comparison of the selectivity in the reaction of various methylation reagents with equimolar mixtures of benzaldehyde and acetophenone: Equation is shown above.

\begin{tabular}{clcl}
\hline Reagent & Reaction condition & Ratio A:B & Remark (note \#) \\
\hline $1^{*}$ & THF, 0 $0^{\circ}, 30 \mathrm{~min}$. & $>99: 1$ & $76 \%$ (SJK-II-32) \\
$\mathrm{CH}_{3} \mathrm{Ti}(\mathrm{Oi}-\mathrm{Pr})_{3}{ }^{b}$ & THF, RT, $24 \mathrm{hr}$. & $>98: 2$ & $>90 \%$ \\
$\mathrm{CH}_{3} \mathrm{Zr}(\mathrm{OBu})_{3}{ }^{\mathrm{c}}$ & $\mathrm{THF}, \mathrm{RT}, 15 \mathrm{hr}$. & $95: 5$ & Incomplete reaction \\
$\mathrm{CH}_{3} \mathrm{Li}^{\mathrm{d}}$ & Ether, $0^{\circ} \mathrm{C}, 1 \mathrm{~min}$. & $50: 50$ & Benzyl alcohol formation \\
\hline
\end{tabular}

a: Reaction ratio was 10 [benzaldehyde]:10[acetophenone]: 1[complex 1]. Yield was calculated by an internal standard method using biphenyl.

b: Prepared by reacting with $\mathrm{CH}_{3} \mathrm{Li}$ with $\mathrm{ClTi}(\mathrm{O} i-\mathrm{Pr})_{3}$, excess $(-15 \%)$ of reagent. ${ }^{2 \mathrm{~s} b}$

c: From $\mathrm{CH}_{3} \mathrm{Li}$ with $\mathrm{ClZr}(\mathrm{OBu})_{3}$, excess of reagent. ${ }^{2 c}$

$\mathrm{d}$ : reaction ratio was 1 [benzaldehyde]:1[acetophenone]: $1\left[\mathrm{CH}_{3} \mathrm{Li}\right] .{ }^{1 \mathrm{c}, 2}$

In our early study ${ }^{3}$ for the in situ generated complex 1 (from $\mathrm{Cp}_{2} \mathrm{Zr}\left(\mathrm{CH}_{3}\right) \mathrm{Cl}$ and excess KOt-Bu system), aldehyde selectivity (95\%) was observed in the competition of benzaldehyde and benzophenone mixtures (see Table 5); the reagent from $\mathrm{Cp}_{2} \mathrm{Zr}\left(\mathrm{CH}_{3}\right)_{2}$ and excess $\mathrm{KO} t-\mathrm{Bu}$ gave even less selectivity ( $86 \%$ to aldehyde). However, the neutral "Seebach reagent" gave much higher aldehyde-selectivity (>99\%) with $94 \%$ yield (Table 5). Considering the different selectivities between our zirconium-base system and the neutral "Seebach reagent", we have suggested the possibility of a zirconium anionic "ate" complex as an active intermediate in the zirconium-base reaction. ${ }^{3 b}$ In this report, as can 
be seen from the results of the same competition reaction with complex 1 (Table 3 and 5), we can achieve a complete aldehyde-selectivity (>99\%) with high yield $(80 \%, 60 \mathrm{~min}$. at $0{ }^{\circ} \mathrm{C}$ ). It may be suggested that the presence of base or $\mathrm{KCp}$ with complex 1 gave lower selectivity in the in situ zirconium-base system, and it also prevented the methylation of enolizable ketones [We could test this by adding $\mathrm{KO} t-\mathrm{Bu}$ (and $\mathrm{KCp}$ ) to complex 1].<smiles>[CH2+]C(O)c1ccccc1C(O)c1ccccc1</smiles>

A

B

Table 5. Comparison of the selectivity in the reaction of various methylation reagents with equimolar mixtures of benzaldehyde and benzophenone: Equation is shown above.

\begin{tabular}{clcl}
\hline Reagent & Reaction condition & Ratio A:B & Yield (note \#) \\
\hline $\mathbf{1}^{2}$ & $\mathrm{THF}, 0^{\circ} \mathrm{C}, 60 \mathrm{~min}$. & $>99: 1$ & $76 \%$ (SJK-II-21) \\
$\mathrm{Cp}_{3} \mathrm{Zr}\left(\mathrm{CH}_{3}\right)_{2} / \mathrm{KO} t-\mathrm{Bu}^{b}$ & $\mathrm{THF}, 0^{\circ} \mathrm{C}, 60 \mathrm{~min}$ & $86: 14$ & Ref. 3b. \\
$\mathrm{Cp}_{3} \mathrm{Zr}\left(\mathrm{CH}_{3}\right) \mathrm{Cl} / \mathrm{KOt}-\mathrm{Bu}^{b}$ & $\mathrm{THF}, 0^{\circ} \mathrm{C}, 60 \mathrm{~min}$. & $95: 1$ & $72 \%$ (RWT-II-121) \\
$\mathrm{CH}_{3} \mathrm{Zr}(\mathrm{OBu})_{3}{ }^{c}$ & Ether, $0^{\circ} \mathrm{C}, 60 \mathrm{~min}$. & $>99: 1$ & $93 \%$ (RWT-II-15) \\
\hline
\end{tabular}

a: reaction ratio was 10 [benzaldehyde]: 10 [benzophenone]: 1 [complex 1]. Yield was calculated by an internal standard method using biphenyl, based on two methyl groups transfer.

b: Prepared by reacting with $\mathrm{Cp}_{3} \mathrm{Zr}\left(\mathrm{CH}_{3}\right)_{2}$ (or $\mathrm{Cp}_{3} \mathrm{Zr}\left(\mathrm{CH}_{3}\right) \mathrm{Cl}$ ) and $4 \mathrm{KO} t-\mathrm{Bu} ; 10$ fold excess of carbonyl substrates. ${ }^{3 \mathrm{~b}}$

c: Prepared in situ from $\mathrm{CH}_{3} \mathrm{Li}$ with $\mathrm{ClZr}(\mathrm{OBu})_{3}$ in ether; 2.5 fold excess of carbonyl substrates. $^{3 b}$ 


\section{Diastereoselectivity}

Generally, in the methylation of 4-tert-butylcyclohexanone, whose conformation was "locked", classical reagents such as $\mathrm{CH}_{3} \mathrm{Li}$ and $\mathrm{CH}_{3} \mathrm{MgI}$ slightly prefer equatorial attack, generating the axial alcohol (about 2:1 ratios of A:B in Scheme 3, see also entry 10 and 11 in Table 6) because steric interaction of the incoming reagent with the 3,5-axial hydrogens is greater than torsional strain with the 2,6-axial hydrogens (see Scheme 3). ${ }^{\text {la }}$ The selectivity can be improved with excess of $\mathrm{CH}_{3} \mathrm{Li}_{-} \mathrm{CH}_{3} \mathrm{CuLi}$ or with $\mathrm{CH}_{3} \mathrm{Li}-\mathrm{LiClO}$, (92 or $94 \%$ equatorial attack). ${ }^{5}$ Recently, the transmetallation of $\mathrm{CH}_{3} \mathrm{Li}$ with $\mathrm{FeCl}_{3}$ gave the unprecedented value of $99 \%$ equatorial attack with $98 \%$ GC yield. ${ }^{6}$ Therefore, it is of interest to test the diastereoselectivity of complex 1 as a methylation reagent.

\section{Scheme 3.}

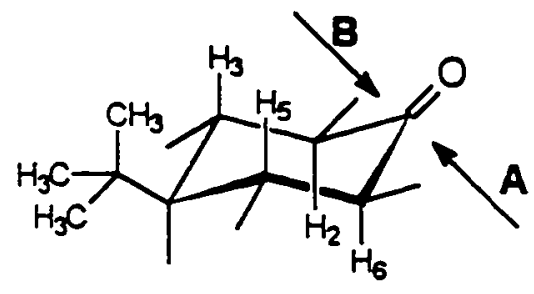

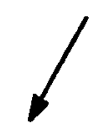

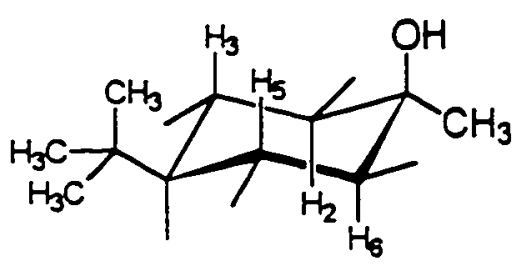

A

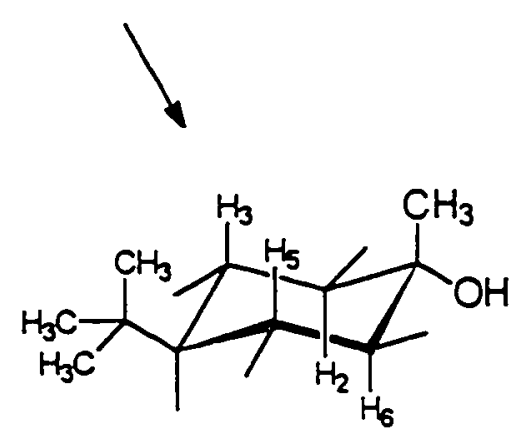

B 
Table 6. Diasteroselective addition to 4-tert-butylcyclohexanone

\begin{tabular}{|c|c|c|c|c|c|}
\hline Entry & Reagent & Reaction Condition & $A: B$ & Yield & Note \\
\hline 1 & $1^{2}$ & $\mathrm{THF}, 0^{\circ} \mathrm{C}, 30 \mathrm{~min}$. & $80: 20$ & $90 \%$ & SJK-I-I34 \\
\hline 2 & $1 *$ & Ether, $0^{\circ} \mathrm{C}, 30 \mathrm{mir}$. & $75: 25$ & $67 \%$ & SJK-I-137 \\
\hline 3 & $1^{2}$ & THF, $-50^{\circ} \mathrm{C}$ to $-10^{\circ} \mathrm{C}, 1 \mathrm{hr}$. & $85: 15$ & $84 \%$ & SJK-I-140 \\
\hline 4 & $1^{2}$ & $\mathrm{THF}, 50^{\circ} \mathrm{C}, 30 \mathrm{~min}$. & $82: 18$ & $98 \%$ & SJK-I-150 \\
\hline 5 & $(\mathrm{BuO})_{3} \mathrm{ZrCH}_{3}{ }^{b}$ & Ether, $20^{\circ} \mathrm{C}, 15 \mathrm{hr}$. & $80: 20$ & $95 \%$ & Ref. 2 \\
\hline 6 & (tritox) $)_{2} \mathrm{Zr}\left(\mathrm{CH}_{3}\right)_{2}$ & THF, $0^{\circ} \mathrm{C}, 2 \mathrm{hr}$ & $79: 21$ & $28 \%$ & DSSH-I-139? \\
\hline 7 & $\mathrm{CH}_{3} \mathrm{Ti}(\mathrm{O} i-\mathrm{Pr})_{3}{ }^{e}$ & Hexane, $-15-22^{\circ} \mathrm{C}, 24 \mathrm{hr}$. & $94: 6$ & $89 \%$ & Ref. 1 \\
\hline 8 & $\left(\mathrm{CH}_{3}\right)_{2} \mathrm{Ti}(\mathrm{O} i-\mathrm{Pr})_{2}$ & $\mathrm{CH}_{2} \mathrm{Cl}_{2},-40^{\circ} \mathrm{C}$ & $75: 25$ & $90 \%$ & Ref. 1 \\
\hline 9 & $\mathrm{CH}_{3} \mathrm{Ti}(\mathrm{O} i-\mathrm{Pr})_{4} \mathrm{MgCl}^{\bullet}$ & Ether, $-40^{\circ} \mathrm{C}$ & $33: 67$ & - & Ref. 1 \\
\hline 10 & $\mathrm{CH}_{3} \mathrm{MgI}$ & Ether, $0^{\circ} \mathrm{C}$ & $62: 38$ & - & Ref. 1 \\
\hline 11 & $\mathrm{CH}_{3} \mathrm{Li}$ & Ether, $0^{\circ} \mathrm{C}$ & $65: 35$ & - & Ref. 1 \\
\hline
\end{tabular}

a: reaction ratio was $1: 1([$ Ketone]:[Complex]) and yield was based on one methyl group transferred.

b: In situ mode of reaction, i.e., $\mathrm{LiCl}$ was present.

c: The reagent was distilled, i.e., no salts was present.

In the methylation of 4-tert-butylcyclohexanone (entry $1-4$, Table 6), complex 1 gave preferential equatorial attack with high yields and a fast reaction. At $0{ }^{\circ} \mathrm{C}$ in THF the diastereoselectivity was $80 \%$ (yield $90 \%$ ), and this was improved to $85 \%$ at lower temperatures. The reaction in ether (entry 2) was slow (yield $67 \%$ ), and the selectivity was slightly lower than in THF reactions (entry 1,2 and 3 ). At $50^{\circ} \mathrm{C}$, the axial and equatorial ratio was $82: 18$ with $98 \%$ yield for $30 \mathrm{~min}$. reaction (entry 4 ). This reaction was comparable to that of $(\mathrm{BuO})_{3} \mathrm{ZrCH}_{3}$ (Seebach reagent, entry 5) which was $80 \%$ diastereoselectivity in a very slow reaction (at $20^{\circ} \mathrm{C}, 15 \mathrm{hr}$ ). In our early work, 
(tritox) $)_{2} \mathrm{Zr}\left(\mathrm{CH}_{3}\right)_{2}$ (entry 6; tritox $=\left(\left(\mathrm{CH}_{3}\right)_{3} \mathrm{C}\right)_{3} \mathrm{CO}^{-}$, see also Eq. 7 in Chapter $\mathrm{D}$ was found to give similar diastereoselectivity (79 \%) in an incomplete reaction (28\% yield).

The titanium analog $\left(\mathrm{CH}_{3}\right)_{2} \mathrm{Ti}(\mathrm{OCHMe})_{2}$ leads to $75 \%$ diastereoselectivity. Except for the reaction with $\mathrm{CH}_{3} \mathrm{Ti}\left(\mathrm{OCHMe}_{2}\right)_{3}$ (entry 7), in which such a drastic increase of diastereoselectivity was achieved by changing solvents and temperature, all the reagents gave lower selectivity than complex 1 did. However, the reaction conditions for complex 1 were not optimized and further work might improve this selectivity.

\section{Future work.}

We need more systematic reactions to test complex 1 as a methylation reagent such as following experiments may be needed:

1) reaction of the mixture of complex 1 and $\mathrm{KO} t-\mathrm{Bu}$ (and $\mathrm{KCp}$ ) with enolizable ketones or competition reactions to confirm the in situ generated complex 1 (from $\mathrm{Cp}_{2} \mathrm{Zr}\left(\mathrm{CH}_{3}\right)_{2}$ and excess $\mathrm{KO} t-\mathrm{Bu}$ ).

2) reaction with 2-phenylpropanal for test of stereoselectivity.

3) competition with benzaldehyde and p-nitrobenzaldehyde for the test of electronic effect.

4) test reactivity with sterically hindered and enolizable ketones. 


\section{Experimental}

A. General Procedures and Materials. All operations were carried out under nitrogen using standard Schlenk techniques and an inert atmosphere-filled glove box.

Benzaldehyde was vacuum distilled and stored in a screw-top bottle under nitrogen. 0 Tolualdehyde was washed with sodium bicarbonate and stored over $3 \mathrm{~A}$ sieves in a screwtop bottle under nitrogen. Potassium fluoride and anhydrous magnesium sulfate (Aldrich), $\alpha$-methylbenzyl alcohol (Eastman Organic Chemicals) were used as received. Biphenyl was recrystallized from toluene. Authentic 1-(o-tolu)ethanol was prepared from the reaction of $o$-tolualdehyde and methyllithum in ether followed by vacuum distillation and transfer to a screw-top bottle to be stored under nitrogen. An authentic methylated alcohol product of mesitaldehyde was prepared by sodium borohydride reduction of $\left(2^{\prime}, 4^{\prime}, 6^{\prime}\right.$-trimethyl)-acetophenone in ether followed by purification and by recrystallization from hexane. trans-4-tert-Butyl-1-methylcyclohexanol was prepared from 4-tert-butyl-1methylcyclohexanone and the mixture of two parts $\mathrm{CH}_{3} \mathrm{Li}$ and one part $\mathrm{LiClO}_{4}$ using method developed by Ashby. ${ }^{\text {Sa }}$ cis-4-tert-Butyl-1-methylcyclohexanol was prepared by addition of $\mathrm{CH}_{3} \mathrm{Li}$ to 4-tert-butylcyclohexanone.

Gas chromatography was performed using a Hewlett-Packard HP 5880A Gas Chromatograph with FDD detection. The chromatographic conditions were as follows: DB5 column, $0.25 \mu \mathrm{m}$ film thickness, $30 \mathrm{~m} \times 54 \mu \mathrm{m}$; injector, $250^{\circ} \mathrm{C}$; detector, $300^{\circ} \mathrm{C}$; initial temperature/time, $40^{\circ} \mathrm{C} / 0 \mathrm{~min}$; programmed rate, $30^{\circ} \mathrm{C} / \mathrm{min}$.; final temperature/time, $220^{\circ} \mathrm{C} / 5 \mathrm{~min}$. 


\section{B. Specific Procedures}

1. Preparation of a standard solution for gas chromatography. To $10 \mathrm{~mL}$ ether was added biphenyl $(45.3 \mathrm{mg}, 0.29 \mathrm{mmol})$, benzaldehyde $(50 \mu \mathrm{L}, \mathrm{d}=1.044,0.49$ mmol), $o$-tolualdehyde $(60 \mu \mathrm{L}, \mathrm{d}=1.039,0.52 \mathrm{mmol}), \alpha$-methylbenzyl alcohol $(50 \mathrm{~mL}, \mathrm{~d}$ $=1.018,0.42 \mathrm{mmol})$, and l-o-toluethanol $(50.0 \mathrm{mg}, 0.365 \mathrm{mmol})$ and this mixture was subjected to analysis by gas chromatography. Molar correction factors were calculated for use in all analytical work which followed.

2. Example of a competition reaction. Here, we describe competition reaction of 10:10 mixture of benzaldehyde and acetophenone with one equivalent of complex 1 as a typical reaction. In general, the reaction was carried out in a $5-\mathrm{mL}$ ampule equipped with an efficient stirring bar and rubber septum. The $5 \mathrm{~mm}$ NMR tube septa from Aldrich were well fitted. During the reaction, the ampule was always kept under positive nitrogen pressure by connecting to the Schlenk line via a needle.

To a flame dried $5 \mathrm{~mL}$-ampule (with a rubber septum) were added complex 1 (28 $\mathrm{mg}, 0.0737 \mathrm{mmol})$ and biphenyl $(26 \mathrm{mg}, 0.169 \mathrm{mmol})$ in the glove box. THF ( $3 \mathrm{~mL})$ was added via cannula under nitrogen at $0^{\circ} \mathrm{C}$. To a second $5 \mathrm{~mL}$-ampule (with a rubber septum and magnetic bar) were added benzaldehyde $(76 \mu \mathrm{L}, 0.757 \mathrm{mmol})$ and acetophenone ( $86 \mu \mathrm{L}, 0.757 \mathrm{mmol})$ via micro-syringe, and added $3 \mathrm{~mL}$ THF at $0{ }^{\circ} \mathrm{C}$ via cannula. The solution of complex 1 and biphenyl in THF was added to the mixture of 
benzaldehyde and acetophenone in THF via cannula at $0^{\circ} \mathrm{C}$, during which time a colorless solution changed to a pale-yellow solution from the first drops complex 1 solution. The resulting mixture was stirred for $30 \mathrm{~min}$. during which time the yellow color deepened. Cold saturated $\mathrm{KF} / \mathrm{H}_{2} \mathrm{O}$ solution ( $2 \mathrm{~mL}$ ) was added via syringe. Upon adding $\mathrm{KF}$ solution, a white aqueous layer and a clean yellow organic layer separated. After adding $2 \mathrm{~mL}$ ether, the lower aqueous layer was readily removed via syringe from inverted ampule. The organic layer was washed twice with water $(1 \mathrm{~mL}$ each) and dried over anhydrous magnesium sulfate. Without filtering, the yellow supernatant was assayed by gas chromatography. The only alcohol product, $\alpha$-methyl benzylalcohol, was obtained in $76.2 \%(0.112 \mathrm{mmol})$ yield based transfer of two methyl groups $(0.147 \mathrm{mmol})$.

The reaction of aldehydes and ketones with complex 1 , and diastereoselectivity tests followed in the same manner. 


\section{References}

1. (a) Reetz, M. T.; Steinbach, R.; Westermann, J. Peter, R.; Wenderoth, B. Chem. Ber. 1985, 118, 1441. (b) Reetz, M. T.; Westermann, J.; Steinbach, R.; Wenderoth, B.; Peter, R.; Ostarek, R.; Maus, S. Chem. Ber. 1985, 118, 1421. (c) Reetz, M. T. In Topics in Current Chemistry; Boschke, F. L., Ed.; Springer: Berlin, 1982; Vol. 106, pp 1-54. (d) Reetz, M. T.; Westermann, J. Peter, R. Angew. Chem., Int. Ed. Engl., 1980, 19, 1011 .

2. (a) Seebach, D.; Weidmann, B.; Wilder, L. In Modern Synthetic Methods; Scheffold, R., Ed.; Salle: Frankfurt/Sauerlander: Aarau, 1983; Vol. 3, p217. (b) Weidmann, B.; Seebach, D. Angew. Chem. Int. Ed. Engl. 1983, 22, 31-45; Angew. Chem. 1983, 95, 12. (c) Weidmann B.; Maycock, C. D.; Seebach, D. Helv. Chim. Acta 1981, 64, 1552.

3. (a) Larson, A. L.; Baker, D.L.; Towne, R. W.; Straus, D. A. Teteahedron Lett. 1991, 32, 5893. (b) Towne, R. W. M. S. Thesis, San Jose State University, 1994.

4. March, J. Advanced Organic Chemistry, 3rd Ed., John Wiley \& Sons, Inc.; 1985, pp 813-814.

5. (a) Ashby, E. C.; Noding, S. A. J. Org. Chem. 1979, 44, 4371. (b) MacDonald, T. L.; Still, W. C. J. Amer. Chem. Soc. 1975, 97, 5280.

6. Reetz, M. T.; Stanchev, S. J. Chem. Soc., Chem. Commun. 1993, 328.

7. Hammond, S. M.; Straus, D. A., Unpublished results. 